\title{
1 Sources of iron in the Ross Sea polynya in early summer
}

2 L.J.A. Gerringa ${ }^{1}$, P. Laan $^{1}$, G.L. van Dijken ${ }^{2}$, H. van Haren ${ }^{1}$, H.J.W. De Baar ${ }^{1,3}$, K.R. Arrigo ${ }^{2}$,

3 A.-C. Alderkamp ${ }^{2}$

4

5 1: Royal Netherlands Institute for Sea Research (NIOZ), PO Box 59, 1790 AB Den Burg, the

$6 \quad$ Netherlands

7 2: Department of Earth System Science, Stanford University USA

8 3: Department of Ocean Ecosystems, Energy and Sustainability Research Institute Groningen,

9 University of Groningen, Groningen, the Netherlands 


\section{Abstract}

2 Dissolved Fe (DFe) was measured in the Ross Sea Polynya (RSP), Antarctica, during a

3 GEOTRACES cruise between 20 December 2013 and 5 January 2014. DFe was measured over

4 the full water column with special emphasis on samples near the seafloor. In the upper mixed

5 layer, DFe was very low everywhere $(<0.10 \mathrm{nM})$. DFe increased with depth to values between

$6 \quad 0.60$ and $2.76 \mathrm{nM}$ near the seafloor. The highest DFE concentrations were found at stations

7 where a bottom nepheloid layer (BNL) was present (28 out of 32 stations). Deep DFe was lower

8 (0.24- $0.38 \mathrm{nM})$ at stations with no BNL. The main DFe supply to the upper mixed layer was

9 vertical diffusive transport from the seafloor sediments, with a mean flux of $3.3 \times 10^{-8} \mathrm{~mol} \mathrm{DFe}$

$10 \mathrm{~m}^{-2} \mathrm{~d}^{-1}$. DFe fluxes showed large spatial variability of three orders of magnitude and were

11 positively correlated to DFe concentrations near the sediment and vertical turbulent eddy

12 diffusivity $\left(\mathrm{K}_{\mathrm{z}}\right)$ and negatively correlated to water depth. The greatest fluxes were observed

13 above the shallow banks such as Ross and Pennell banks, and sediments with a BNL. We studied

14 the horizontal diffusive transport from Franklin Island as an example of horizontal DFe transport

15 from landmasses. No DFe transport was detected in the upper $100 \mathrm{~m}$ of the water column,

16 probably due to uptake by phytoplankton. However, at 200 and $300 \mathrm{~m}$ depth, the DFe transport

17 at distances between 50 and $100 \mathrm{~km}$ from Franklin Island was as large as the mean diffusive

18 upward transport, indicating the potential importance of landmasses as a local source of DFe.

19 Conversely, no horizontal transport of DFe from banks was detected. In addition, the Ross Ice

20 Shelf (RIS) was a negligible source of DFe. Only the Ice Shelf Water (ISW), a water mass

21 formed under the RIS, contained slightly elevated DFe (0.18-0.26 nM) compared to the

22 surrounding waters. However, this elevated DFe did not reach into the RSP. Icebergs were not

23 encountered and were not evaluated as a DFe source. Overall, we conclude that DFe from the 
1 seafloor and land mass sediments are the main DFe sources of DFe that support phytoplankton in 2 the upper mixed layer of the Ross Sea Polynya in early summer.

3

4 


\section{1. Introduction}

2 Antarctic shelf waters are a strong sink for atmospheric $\mathrm{CO}_{2}$ due to high biological

3 productivity, intense winds, high air-sea gas exchange, formation of bottom water and extensive

4 winter ice cover (Arrigo et al., 2008a; Jones et al., this issue). These factors make these regions

5 important for the biogeochemical cycling of elements, particularly that of carbon (Sarmiento et

6 al., 2004; Arrigo et al., 2008a). Specifically, coastal polynyas (areas of open water surrounded by

7 ice) are hot spots for energy and carbon transfer between the atmosphere and ocean (Smith and

8 Barber, 2007). The reduced ice cover increases air-sea gas exchange and results in enhanced

9 light availability in the near surface waters in early spring, thereby increasing primary

10 productivity through phytoplankton photosynthesis. In addition to its importance for the global

11 carbon cycle, phytoplankton productivity on Antarctic shelves supports the biota of higher

12 trophic levels such as krill, penguins, and whales (Arrigo et al., 2003, Arrigo and Van Dijken

13 2003a; Ainley et al., 2006).

14 In the Southern Ocean, phytoplankton productivity is often limited by the availability of iron

15 (Fe) (de Baar et al., 1990; Martin et al., 1990; 1994; Boyd et al., 2007 and references therein),

16 although light limitation due to deep vertical mixing may also limit phytoplankton growth

17 (Mitchell et al., 1991; De Baar et al., 2005). Fe exists in both dissolved and particulate forms in

18 seawater. Dissolved Fe (DFe) is considered to be the preferred form for phytoplankton, but since

19 Fe has a low solubility in seawater, it easily precipitates or is scavenged, and sinks out of the

20 euphotic zone as particulate Fe (Millero, 1998; Liu and Millero, 1999). The concentrations of

21 DFe in Antarctic waters are controlled by a balance between Fe input from various sources,

22 processes like organic complexation that keep Fe in solution, and removal processes (Gledhill

23 and Van den Berg, 1994; Boyd et al., 2012; Klunder et al., 2011; Thuróczy et al., 2011; 2012). 
1 Dissolved organic ligands are molecules that bind trace metals such as Fe. In this way, the

2 ligands increase the solubility of Fe, retard the precipitation of Fe (hydr-) oxides, and increase Fe

3 availability for biological uptake in the upper ocean. As such, the binding by dissolved organic

4 ligands may play an important role in the dissolution of Fe and keeping Fe in the dissolved

5 phase. It is unknown which fraction of the organically complexed Fe pool can be directly utilized

6 by phytoplankton and how it is taken up (Hassler et al, 2012; Gledhill and Buck, 2012).

$7 \quad$ Potential sources of DFe in Antarctic waters are upwelling of DFe-rich deep waters (De Baar

8 et al., 1995; Löscher et al., 1997: Croot et al., 2004; Klunder et al., 2011), melting glaciers, ice

9 sheets, and icebergs (de Baar et al., 1995; Raiswell et al., 2006; 2008; Gerringa et al., 2012;

10 Wadham et al., 2013), melting sea ice (Sedwick and DiTullio, 1997; Lannuzel et al., 2010, 2014;

11 van der Merwe et al., 2011), atmospheric dust deposition either directly into surface waters or

12 onto sea ice (Croot et al., 2007; Sedwick et al., 2008; 2011; de Jong et al., 2013), hydrothermal

13 vents (Tagliabue et al., 2010; Klunder et al., 2011; Hawkes et al., 2013; Aquilina et al., 2014),

14 and sediment resuspension and reductive dissolution (Fitzwater et al., 2000; Sedwick et al, 2011;

15 De Jong et al., 2012; Hatta et al., 2013; Marsay et al., 2014). Sediment resuspension and

16 reductive dissolution are particularly important when a bottom nepheloid layer (BNL) is present,

17 a layer above the sediment that contains significant amounts of suspended sediment, as it is

18 important for exchange of DFe between sediment and water (Bacon and Rutgers van der Loeff,

19 1989; Klunder et al., 2012). Horizontal and vertical advection and diffusion determine the

20 distribution of DFe from these sources (Blain et al., 2007, 2008; Gerringa et al., 2012; de Jong et

21 al., 2012; Bowie et al, submitted), which is facilitated by complexation with dissolved organic

22 ligands (Thuroczy et al. 2011, 2012; Boye et al., 2001; Croot et al., 2004; Gerringa et al., 2008). 
The Ross Sea is one of the most studied coastal regions of Antarctica and the most

2 productive sector of the Southern Ocean (Arrigo and Van Dijken 2003a, Arrigo et al., 2008b).

3 Low DFe concentrations have been reported in the surface waters, which may limit

4 phytoplankton growth (Martin et al., 1990; Sedwick and DiTullio, 1997; Fitzwater et al., 2000;

5 Coale et al., 2005; Sedwick et al. 2011, Marsay et al., 2014). Traditionally, it was thought that

6 DFe concentrations in surface waters were high during the winter and early spring due to

7 remineralization of Fe and vertical mixing that brings deep DFe-rich water to the surface

8 (Sedwick and DiTullio, 1997; Fitzwater et al., 2000; Coale et al., 2005). This winter stock of

9 DFe would then be taken up by phytoplankton over the course of the spring and summer,

10 resulting in seasonal Fe-limitation of phytoplankton growth (Sedwick et al., 2000; Coale et al.,

11 2005). However, Sedwick et al. (2011) showed that even in early spring, before the seasonal

12 peak in phytoplankton abundance, DFe concentrations were already extremely low in surface

13 waters of the Ross Sea Polynya (RSP). These low DFe concentrations were potentially limiting

14 phytoplankton growth and suggest that bioavailable Fe must be supplied throughout the growing

15 season in order to sustain phytoplankton blooms. However, the source of this DFe is unclear. The

16 Ross Ice Shelf (RIS) does not appear to be a major source of DFe to surface waters of the RSP

17 since DFe is relatively low at stations close to the edge of the RIS (Sedwick et al., 2011; Marsay

18 et al., 2014). This contrasts with the Amundsen Sea, where the Pine Island Glacier was the main

19 Fe source for the phytoplankton bloom in the Pine Island Polynya (Gerringa et al, 2012;

20 Alderkamp et al., 2012), and the Dotson Ice Shelf was a major DFe source for phytoplankton in

21 the Amundsen Sea Polynya (Sherrell et al, submitted). Sedwick et al. (2011) suggested that the

22 main Fe sources to surface waters of the Ross Sea were dust deposition, sea ice melt, and vertical

23 exchange of DFe through reductive dissolution of sediments. Marsay et al. (2014) also suggested 
1 that sediment-derived Fe was the most important DFe source. De Jong et al. (2013)

2 acknowledged the importance of dust and sea ice melt but also proposed that sediment-derived

3 Fe from the melting of icebergs and ice sheets was an important DFe source. In contrast, Coale et

4 al. (2005) concluded that DFe transport from the sediment through vertical mixing did not bring

5 DFe to surface waters.

6 The research presented here aims to identify and quantify the sources of DFe that support

7 phytoplankton blooms in the Ross Sea. We present water column DFe concentrations related to

8 water masses in the Ross Sea during December and January when the phytoplankton bloom

9 typically reaches its highest biomass levels (Arrigo and Van Dijken 2003a, Arrigo and Van

10 Dijken, 2004). In particular, we use high spatial resolution DFe concentration data from waters

11 near suspected Fe sources, such as the Ross Ice Shelf, sea ice, sediments, modified Circumpolar

12 Deep Water (MCDW), and land masses (e.g., Franklin Island), to calculate DFe fluxes from

13 these sources to surface waters where it supports phytoplankton growth.

15 2. Methods

$16 \quad$ 2.1. Sampling

17 The cruise NBP13-10 of the RVIB Nathaniel B. Palmer took place from December 2013 to

18 January 2014 as part of the Phantastic project. We entered the Ross Sea from the north-east on

1920 December and left on the north-western side on 5 January (Fig. 1). We sampled a total of 33

20 stations, two stations in the eastern Ross Sea and 31 stations in the RSP (Fig 1). Twenty-five

21 stations made a circle section through the RSP that was sampled starting at station 20, going

22 south to the RIS, and then counter-clockwise (Fig. 1).

23 The following sections will be discussed in detail: 
1) The south-north central RSP transect along the $177.5^{\circ} \mathrm{E}$ meridian from a distance of $10 \mathrm{~km}$

2 from the RIS at $77.74^{\circ} \mathrm{S}$ to the north crossing one trough up to the Ross Bank and crossing a

3 second trough to the Pennell Bank at $74.5^{\circ} \mathrm{S}$. Along this section, we studied surface DFe in

4 relation to water properties in the central RSP and potential DFe sources from the RIS and Ross

5 Bank.

6 2) The east-west Pennell Bank transect along $74.5^{\circ} \mathrm{S}$ from the Pennell Bank at $177.5^{\circ} \mathrm{E}$ to the

7 Joides Trough at $172.5^{\circ}$ E. Here we studied potential DFe sources from the Pennell Bank.

8 3) The west-east Franklin Island transect along $76.1^{\circ} \mathrm{S}$ from $9.5 \mathrm{~km}$ east of Franklin Island at

$9 \quad 168.7^{\circ} \mathrm{E}$ to $169^{\circ} \mathrm{E}$. Along this section, we studied potential DFe sources from Franklin Island.

10 4) The western RSP transect, from station $75\left(74.5^{\circ} \mathrm{S}, 172.5^{\circ} \mathrm{E}\right)$ moving to the south-west to

11 station $87\left(76^{\circ} \mathrm{S}, 170^{\circ} \mathrm{E}\right)$ and from there to the south-east (via st. $\left.91,101,111,112,113\right)$ to

12 station $114\left(77.33^{\circ} \mathrm{S}, 177.5^{\circ} \mathrm{E}\right)$ which is the same position as station 31 of the Central RSP

13 transect. At this section, we studied surface DFe in relation to water properties in the western

14 RSP.

15 All trace metal clean (TMC) water samples were collected using modified 12 L GO-FLO

16 (Oceanics) samplers provided by the Royal NIOZ (the Netherlands) were attached to a TMC

17 frame provided by the United States Antarctic Program. Temperature, depth, and salinity were

18 measured with a SBE 9/11plus conductivity-temperature-depth (CTD) system (SeaBird

19 Electronics). The frame also included a C-star transmissometer (WET Labs) and a chlorophyll $a$

20 (Chl a) fluorometer (WET Labs). Temperature and salinity were transformed into conservative

21 temperature $\left(\Theta\right.$ in $\left.{ }^{\circ} \mathrm{C}\right)$ and absolute salinity $\left(\mathrm{S}_{\mathrm{A}}\right.$ in $\left.\mathrm{g} \mathrm{kg}^{-1}\right)$ according to McDougall et al. (2009).

22 Typical sample depths were 10, 25, 50, 75, 100, and every $100 \mathrm{~m}$, thereafter depending on

23 water depth. Full water column profiles were sampled at 33 stations where the deepest sample 
1 was $6 \pm 4.19 \mathrm{~m}$ above the bottom and an additional sample $10 \mathrm{~m}$ above the deepest sample.

2 Occasionally, surface waters were sampled at 4-5 $\mathrm{m}$ depth.

3 Water was filtered (Sartorius ${ }^{\circledR}, 0.2 \mu \mathrm{m}$; Satrobran 300) prior to DFe analysis (see below)

4 inside a trace metal clean van.

$6 \quad$ 2.2. Analyses

$7 \quad$ 2.2.1. DFe determination with Flow Injection Analysis

8 Trace metal clean work was done free from contamination in a plastic bubble on the ship.

9 Overpressure in the bubble was achieved by inflow of air through a HEPA filter. Sample

10 handling was done within a laminar flow bench inside the bubble.

11 DFe concentrations were measured directly on board by the automated Flow Injection

12 Analysis (FIA) method (Klunder et al., 2011). Filtered and acidified (Seastar@ baseline

13 hydrochloric acid; $\mathrm{pH}$ 1.7) seawater was concentrated on a column containing amino-di-acetic

14 acid (IDA). Samples were analysed in triplicate and standard deviations (SD) are given. DFe

15 concentrations ranged from $21 \mathrm{pM}$ to $2.765 \mathrm{nM}$ with the median at $0.124 \mathrm{nM}$. The mean SD of

16 triplicate measurements was $2.7 \%$ of the DFe concentration. Blanks were determined daily by

17 calculating the intercept of a seawater sample loaded for 0, 5 and $10 \mathrm{~s}$. The blank values ranged

18 from undetectable to $14 \mathrm{pM}$. The limit of detection of $16 \mathrm{pM}$ was defined as 3 times the SD of

19 the mean of the daily measured blanks.

20 The consistency of the FIA system over the course of a day was verified by measuring the

21 same seawater sample several times. The observed drift was less than $5 \%$ and no corrections

22 have been made for this drift. A certified SAFe standard (Johnson et al., 2007) for the long term 
1 consistency and absolute accuracy was measured on a regular basis (SAFe D2 (\#94) 1.012 \pm 0.015

2 nM Fe, n=9; SAFe S (\#173, 453, 87) 0.071 \pm 0.010 nM Fe, n=18).

4 2.2.2. Vertical turbulent eddy diffusivity estimates using CTD-data

5 CTD samples were obtained at a rate of $24 \mathrm{~Hz}$. The average lowering speed was $0.4 \mathrm{~m} \mathrm{~s}^{-1}$, so

6 that measurements are made about every $0.017 \mathrm{~m}$. During post-processing using SBE-software,

7 potential surface-wave-influences, that may reverse direction of motion of the package, are

8 filtered out by restricting to a CTD-speed of $>|0.25| \mathrm{m} \mathrm{s}^{-1}$, whereby direction changes are

9 removed. Corrections for thermal inertia of conductivity cells are applied and the data are

10 transferred into $0.33 \mathrm{~m}$ vertical bins, thereby averaging some 20 data points per bin. This is

11 consistent with the typical turbulent overturn-scale of $0.4 \mathrm{~m}$ that is resolvable using CTD-data

12 (Stansfield et al., 2001). Ideally, it is preferred to use temperature-only data as a tracer for

13 density to compute turbulence parameters, under the condition of a tight T-S relationship. This

14 holds not only in lakes, as in the original paper by Thorpe (1977), but also in the ocean, as CTD-

15 computed density (anomaly) data are 3-10 times noisier than density from temperature alone

16 (Stansfield et al., 2001; van Haren and Gostiaux, 2014). However, for polar regions where many

17 salinity compensated intrusions exist (e.g. due to ice effects), the density data from the CTD is

18 used to estimate turbulence parameters (Gargett and Garner, 2008).

19 The vertical turbulent eddy diffusivity $\left(\mathrm{K}_{\mathrm{z}}\right)$ was estimated by calculating the 'Thorpe scale'

$20 \quad\left(\mathrm{~d}_{\mathrm{T}}\right)$ using the $0.33 \mathrm{~m}$ binned CTD- $\sigma_{\theta}$ (sigma-theta, density anomaly referenced to the surface)

21 data. The parameter $\mathrm{d}_{\mathbf{T}}$ is a vertical length scale of turbulent mixing in a stratified flow (Thorpe,

22 1977). It is obtained by rearranging an observed potential density profile, which may contain

23 inversions associated with turbulent overturns, into a stable profile without inversions. The 
1 vertical displacement necessary to generate the stable profile is the 'Thorpe displacement'. A

2 threshold of $0.0005 \mathrm{~kg} \mathrm{~m}^{-3}$ is used to discard apparent displacements associated with

3 instrumental noise, as in Gargett and Garner (2008). These authors also propose to test for

4 (a)symmetric distribution of positive and negative displacements to rule out spikes. In the present

5 data, mostly obtained in good weather conditions, nearly all displacements passed this test,

6 implying effective removal of spikes by the post-processing. Defining $d_{T}$ as the root mean square

7 of the Thorpe displacements within each turbulent overturn, the eddy diffusivity $\left(\mathrm{m}^{2} \mathrm{~s}^{-1}\right)$ is

8 obtained as:

$$
\mathrm{K}_{\mathrm{z}}=0.128 \mathrm{~d}_{\mathrm{T}}^{2} \mathrm{~N}
$$

10 where $\mathrm{N}$ denotes the buoyancy frequency and the constant 0.128 is derived from an empirical

11 relation with the Ozmidov scale, the largest overturn scale in stratified waters, using a constant

12 mixing efficiency of 0.2, which is typical for shear-induced turbulence (Dillon, 1982). The

13 method of overturn displacements provides a reasonably adequate estimate of $K_{\mathbf{z}}$ and the

14 turbulence dissipation rate to within a factor of two, as has been established after comparison

15 with independent estimates using free-falling microstructure data (e.g., Hosegood et al., 2005).

16 The raw $\mathrm{K}_{\mathrm{z}}(\mathrm{z})$ profiles were averaged in $50 \mathrm{~m}$ vertical bins, similar to the largest

17 displacement observed, over which mean $\mathrm{K}_{\mathrm{z}}$ values were calculated. When a BNL was present, a

18 separate mean $\mathrm{K}_{\mathrm{z}}$ was calculated for this layer and another for the water column between the

19 BNL and the upper mixed layer, which was defined above the depth where the density was 0.02

$20 \mathrm{~kg} \mathrm{~m}^{-3}$ higher than at the surface. At stations without a BNL, a single mean $\mathrm{K}_{\mathrm{z}}$ value was

21 calculated for the depth-range between the upper mixed layer and the deepest sample. The mean

$22 \mathrm{~K}_{\mathrm{z}}$ values have a standard error of a factor of two times the mean and were used to calculate

23 vertical fluxes. If a BNL was present, two fluxes were calculated, one over the steep DFe 
1 gradient from the BNL into the water just above the BNL and one from the water just above the

2 BNL to the upper mixed layer. At these stations DFe gradients were calculated using mean

3 values of DFe in the BNL, just above the BNL and in the upper mixed layer. If only one

4 concentration was available for any of these layers, this concentration was used instead of a

5 mean.

6 The horizontal turbulent fluxes of DFe from potential sources in the RSP were calculated

7 using the horizontal turbulent diffusivity $\left(\mathrm{K}_{\mathrm{h}}\right)$. To do this, the concentrations $(\mathrm{C})$ of $\mathrm{DFe}$ (in $\mathrm{nM}$

$8 \mathrm{~m}^{-3}$ ) were fit exponentially to the equation:

$$
C(x)=C_{0} e^{-x / D}
$$

10 where $C_{0}$ is the concentration at the source, $x$ is the distance from the source $(m)$, and $D$ is the

11 scale length $(\mathrm{m})$, defined as the distance where $\mathrm{C}(\mathrm{x})=0.37 \mathrm{C}_{0}$ (i.e. the concentration has decreased

12 to $37 \%$ of the initial concentration). Once D was determined, we used the Okubo (1971)

13 parameterization to estimate the $K_{h},\left(\mathrm{~m}^{2} \mathrm{~s}^{-1}\right)$ :

$$
\mathrm{K}_{\mathrm{h}}=7.3 \times 10^{-4} \mathrm{D}^{1.15} \text {, }
$$

15 in which a 95\% reduction length-scale $l$ is used, $l=3 \mathrm{D}$.

16 The horizontal turbulent flux (in $\mathrm{nM} \mathrm{m}^{2} \mathrm{~s}^{-1}$ ) follows from:

$$
\mathrm{F}=\mathrm{K}_{\mathrm{h}} \partial \mathrm{C} / \partial \mathrm{x}
$$

18 or:

$$
F(x)=-7.3 \times 10^{-4} D^{0.15} C(x) .
$$


Four main water masses can be distinguished in the Ross Sea, Antarctic Surface Water

2 (AASW), Winter Water (WW), Shelf Water (SW), and Modified Circumpolar Deep Water

3 (MCDW). AASW is defined by $\boldsymbol{\Theta}>-1.85^{\circ} \mathrm{C}$ and neutral density $<28 \mathrm{~kg} \mathrm{~m}^{-3}$ (Tomczak and

4 Godfrey 2001; Orsi and Wiederwohl 2009), but shows a large variation in temperature and

5 salinity. AASW is present as surface water throughout the Ross Sea, from which WW, defined

6 by a temperature minimum as the remnant of the water mass formed during the previous winter

7 under the warmer upper mixed layer, can be formed. WW was found in the central Ross Sea

8 north of station 46, at stations 47, 49, 59 and 60 (Fig. 2B and C, 3D).

9 SW is formed near the RIS due to sea ice formation and melting. It is very cold $\left(\boldsymbol{\Theta}<-1.85^{\circ} \mathrm{C}\right)$

10 and has variable salinity, depending on salt rejection processes. In the Ross Sea, SW can be

11 divided into Ice Shelf Water (ISW) with $\boldsymbol{\Theta}<-1.95^{\circ} \mathrm{C}$, low salinity SW (LSSW with S <34.62),

12 and high salinity SW (HSSW with S >34.62) (Orsi and Wiederwohl, 2009). ISW was recognised

13 at station 44 and 45 close to the RIS, where $\boldsymbol{\Theta}<-2^{\circ} \mathrm{C}$ at depths of 253 and $227 \mathrm{~m}$, respectively.

14 Stations 49 and 61 were the most northern stations where SW, now Modified Shelf Water

15 (MSW), was present at the bottom (Fig. 2A-2D). LSSW was found in the eastern Ross Sea and

16 can be distinguished from the HSSW in the central and western Ross Sea by its lower salinity

17 (Fig 2A). In the western and central Ross Sea HSSW is flowing through the Drygalski and Joides

18 Trough towards the shelf break (Jacobs et al, 1970 and 2002; Orsi and Wiederwohl, 2009) (Figs

19 2B and C, Figs 4E and D). SW flows cyclonically through the troughs to the shelf break, during

20 which time it becomes MSW by mixing with the AASW and the incoming MCDW. MSW has

21 characteristics between SW and Circumpolar Deep Water (CDW), with a broad range of

22 salinities $>34.5$ and $\boldsymbol{\Theta}>-1.85^{\circ} \mathrm{C}$ ( Orsi and Wiederwohl, 2009) 
Although $\Theta$ and S varied greatly in AASW, its salinity was always lower than the two deeper

2 water masses, SW and CDW (Fig. 2). This was due to melting of the RIS in the south and to

3 melting of sea ice elsewhere. The freshest AASW was found in surface waters of the Franklin

4 Island transect at stations 87 and 90 (salinities of 33.9 and 34.0, respectively, Fig. 2D). Here, sea

5 ice coverage was high (>50\%), suggesting the low salinity resulted from sea ice melt.

6 MCDW is characterized by a temperature maximum at depths between 200 and $400 \mathrm{~m}$ in the

7 Ross Gyre (Jacobs et al., 2002) with a salinity between 34.5 and 35.0 and $\Theta>0{ }^{\circ} \mathrm{C}$ (Orsi and

8 Wiederwohl, 2009). MCDW is formed at the shelf break where CDW flows onto the shelf from

9 the north and mixes with SW and AASW, making MCDW colder and fresher, and therefore less

10 dense, than CDW.

11 The presence of MCDW can be recognised in the $\Theta-S$ plots (Fig 2B, C) and transect plots

12 (Figs 3, 4) by the elevated temperatures from mid-depth to the bottom. MCDW was located

13 along the bottom as far south as $74.4^{\circ} \mathrm{S}$ between $175.7^{\circ} \mathrm{E}$ and $176.5^{\circ} \mathrm{E}$; (between st. 61 and 63)

14 and as far south as $75.5^{\circ} \mathrm{S}$ along $177.5^{\circ} \mathrm{E}$ (between st. 60 and 59). Further south, MCDW was

15 found higher up in the water column, between MSW and AASW, and as far south as $76.75^{\circ} \mathrm{S}$

16 (between st. 46 and 47 along $177.55^{\circ} \mathrm{E}$ ). The water properties at the Pennell Bank transect (Figs.

17 2C and 4) showed that the influence of MCDW, shown by the elevated $\Theta$, decreased west of

18 station 61. Apparently, MCDW entered this part of the Ross Sea Shelf predominantly over the

19 Pennell Bank and on the eastern side of the Joides Trough.

\section{3.2. DFe}

22 In general, DFe was very low (0.02-0.08 nM) in the upper $100 \mathrm{~m}$ of the water column and 23 increased with depth (Figs. 3A-6A, and Supplementary Materials Table 1). Low surface 
1 concentrations were observed in the AASW and WW (st. 47, 49-60), SW (st. 20, 30, 46, 85, 91

2 and 112) and occasionally extended into the MCDW (st. 60). The DFe concentrations were very

3 low where phytoplankton biomass, as measured by fluorescence (Fig 3-6), was high, suggesting

4 biological DFe uptake. Low DFe waters ( $<0.1 \mathrm{nM}$ ) extended from the surface to $100 \mathrm{~m}$ depth in

5 the southern RSP, close to the RIS (st.44, 45, 46) and in the northwest (st. 75 -91). In the central

6 RSP and middle of the western RSP transect (st. 101- 113), low DFe waters were found as deep

7 as $200 \mathrm{~m}$. At stations where deep waters had low DFe, phytoplankton biomass also extended

8 deeper into the water column than at stations where low DFe was restricted closer to the surface.

9 Indications of DFe input at the surface from melting sea ice or dust deposition were only

10 found at station 60, the only station in the RSP with relatively high surface DFe concentrations

11 (0.18 $\mathrm{nM}$ DFe at $5 \mathrm{~m}$ and $0.20 \mathrm{nM}$ DFe at $10 \mathrm{~m}$ depth). Also, the adjacent station 59 showed a

12 small subsurface maximum of $0.1 \mathrm{nM}$ DFe at $25 \mathrm{~m}$ depth, but no elevated surface DFe.

13 Moreover, the upper $100 \mathrm{~m}$ of the Franklin Island transect with $>50 \%$ sea ice cover only had

14 slightly higher DFe concentrations than stations without sea ice (0.08 $\mathrm{nM}$ versus the mean of

$150.06 \mathrm{nM}$ with $\mathrm{SD}=0.03, \mathrm{n}=114$ ). In stations of the Franklin Island transect, DFe increased with

16 depth from $0.06 \mathrm{nM}$ at $10 \mathrm{~m}, 0.08-0.09 \mathrm{nM}$ at $35 \mathrm{~m}$ and $>0.1 \mathrm{nM}$ at $100 \mathrm{~m}$.

17 The potential of the RIS as a DFe source to the RSP was studied at stations nearby (st. 44 and

18 45). DFe maxima of 0.18 and $0.26 \mathrm{nM}$ were found at a depth of $227 \mathrm{~m}$ at station 44 closest to the

19 RIS and at $255 \mathrm{~m}$ at station 45, respectively (Fig. 7B). These maxima coincided with a distinct

20 temperature minimum (below $-2^{\circ} \mathrm{C}$ ), indicative of ISW (Fig. 3). The slightly elevated DFe of

$210.15 \mathrm{nM}$ at $120 \mathrm{~m}$ at station $43(27.7 \mathrm{~km}$ to the north of st. 44$)$ may be related to the outflow of

22 ISW, $\left(\Theta=-1.88^{\circ} \mathrm{C}\right)$. Our data show that the coincidence of maximum DFe and minimum

23 temperature did not extend $>30 \mathrm{~km}$ from the RIS. 
The Franklin Island transect was sampled to study the importance of landmasses such as

2 islands as a source of water column DFe. At depths between 75 and $400 \mathrm{~m}$, DFe concentrations

3 were indeed higher at the station closest to Franklin Island (st. 88) compared to the three stations

4 further away (Fig 7E), suggesting a potential subsurface source from Franklin Island. However, 5 another source cannot be excluded.

6 In general, DFe increased with depth in the RSP, which is indicative of Fe sources from

7 either deep water masses such as MCDW or the sediment. DFe in bottom waters near the

8 sediments exhibited considerable variation throughout the study region (from $0.23 \mathrm{nM}$ at $273 \mathrm{~m}$

9 at st. 60 to $2.76 \mathrm{nM}$ at $753 \mathrm{~m}$ at st. 44), but we did not observe any spatial patterns with

10 geographical location. For instance, DFe in bottom waters was relatively low, between 0.23 and

110.39 nM, at station 44 and 45 near the RIS and station 60 on Pennell Bank (0.39, 0.32 and 0.23

$12 \mathrm{nM}$ DFe, respectively). Intermediate concentrations between 0.5 and $0.7 \mathrm{nM}$ DFe were observed

13 at stations 46, 59, 85 and 101, and high concentrations up to 1.23-2.76 nM were measured at

14 stations 43, 75 and 86. All stations with elevated DFe near the seafloor coincided with decreased

15 transmissometer readings, indicative of a BNL (Figs 3-6). At most stations with a BNL we

16 observed an increase in DFe concentrations from $\sim 6$ to $~ 16 \mathrm{~m}$ above the sea floor. This feature

17 was most distinct at station 114, where the BNL was sampled at three depths and the highest DFe

18 concentration was found in the upper sample $70 \mathrm{~m}$ from the bottom (Fig. 7F). Here, the reduced

19 transmission indicative of a BNL reached $100 \mathrm{~m}$ from the seafloor.

20 At two stations south of $76^{\circ} \mathrm{S}$ in the central RSP (st. 20, 46) and at $77^{\circ} \mathrm{S}$ along the western

21 RSP transect (st. 91), low transmission (93.6-98.2\%) was found throughout the water column

22 (Fig 3, 6). This reduced transmission was not accompanied by enhanced fluorescence (<0.5 a.u.),

23 suggesting that it was not caused by phytoplankton. At these stations, it appeared that fine 
1 suspended particles reached high enough concentrations throughout the water column to reduce

2 transmission to the same degree as in a BNL. In contrast with a BNL, the reduced transmission

3 was not associated with increased DFe. For example, station 20 exhibited relatively low and

4 variable transmission over the entire water column, indicative of suspended particles, whereas

5 station 45 did not show reduced transmission in the water column below the photic zone.

6 However, the DFe depth profiles in the upper $200 \mathrm{~m}$ of both stations are similar (Fig 7C).

\section{Discussion}

9 DFe was very low, on average $0.060 \mathrm{nM}(\mathrm{SD}=0.028)$, throughout the upper $100 \mathrm{~m}$ of the 10 water column of the RSP from December 20 to January 5, in general agreement with previous

11 DFe measurements from the Ross Sea (Sedwick and DiTullio, 1997; Fitzwater et al., 2000;

12 Coale et al., 2005; Sedwick et al., 2011; Marsay et al., 2014). DFe reached high concentrations at 13 depth (mean $0.70 \mathrm{nM}$; SD=0.58) as was also observed by Coale et al. (2005) and Marsay et al.

14 (2014). The low DFe in surface waters suggests biological uptake of all bioavailable DFe by

15 phytoplankton and an absence of Fe supply in excess of uptake by phytoplankton. Our sampling

16 period coincided with the annual early summer phytoplankton bloom in the RSP, with mean

17 phytoplankton biomass in surface waters of $4.3 \mu \mathrm{g} \mathrm{Chl} a \mathrm{~L}^{-1}$ and primary productivity rates of

$180.9 \mathrm{~g} \mathrm{C} \mathrm{m}^{-2} \mathrm{~d}^{-1}$ (Alderkamp et al, in prep). This phytoplankton productivity, despite the

19 consistently low DFe in surface waters at levels considered to be growth limiting for

20 phytoplankton (Timmermans et al., 2001; 2004; Garcia 2009), suggests that Fe is being supplied

21 to the phytoplankton bloom in the RSP throughout the growth season. Moreover, similarly low

22 DFe in surface waters of the RSP was observed in early spring, from 16 November - 3

23 December 2006 , before the peak of the phytoplankton bloom, (Sedwick et al., 2011), confirming 
1 DFe depletion very early in the growing season and the need for new sources of Fe to surface

2 waters to sustain the phytoplankton bloom.

$4 \quad 4.1$ DFe requirements for phytoplankton blooms in the RSP

5 The RSP is the most productive Antarctic polynya, with the annual phytoplankton bloom

6 usually beginning in early November and continuing through February. The bloom typically

7 peaks in December when satellite observations show mean surface Chl $a$ concentrations of 1.95

$8 \pm 0.86 \mu \mathrm{g} \mathrm{L}^{-1}$ (Arrigo and Van Dijken 2003a, Arrigo et al., in prep). Mean in situ surface Chl $a$

9 observations during December are even higher 4.97 $\pm 1.2 \mu \mathrm{g} \mathrm{L}^{-1}$ (Smith et al., 2003; 2006). We

10 used the satellite derived mean Chl $a$ of $1.95 \mu \mathrm{g} \mathrm{L}^{-1}$ from the December climatology for the RSP

11 to calculate the DFe requirements of the phytoplankton during the peak of the bloom in the RSP.

12 We assumed a C:Chl $a$ ratio of $100 \mathrm{~g} \mathrm{~g}^{-1}$ (Thompson et al., 1992) and an Fe:C ratio that ranges

13 from 0.4 to $8.6 \mu \mathrm{mol} \cdot \mathrm{mol}^{-1}$ (Strzepek et al., 2011), in agreement with to the $6-14 \mu \mathrm{mol} \cdot \mathrm{mol}^{-1}$

14 estimated by Twining et al. (2004) for natural phytoplankton populations under Fe-depleted

15 conditions before Fe-enrichment during SOFEX. We calculated the Fe associated with

16 phytoplankton to be 0.007 to $0.14 \mathrm{nM}\left(\mu \mathrm{g}\right.$ Chl $a \mathrm{~L}^{-1} \times \mathrm{mg}$ C:mg Chl $a \times \operatorname{mmol~C:12~mg~C~} \times$

$17 \mathrm{nmol}$ Fe: $\mathrm{mmol} \mathrm{C}=\mathrm{nmol} \mathrm{Fe}$ ). Assuming an in situ phytoplankton growth rate of $0.13 \mathrm{~d}^{-1}$

18 (Alderkamp et al., unpublished data), and no remineralization of Fe from phytoplankton, the net

19 flux of DFe necessary to sustain the observed phytoplankton bloom in an upper mixed layer of

$2050 \mathrm{~m}$ (average mixed layer depth) would be 0.4 to $9.1 \times 10^{-7} \mathrm{~mol} \mathrm{Fe} \mathrm{m}^{-2} \mathrm{~d}^{-1}\left(0.007-0.14 \times 10^{-9} \mathrm{~mol}\right.$

21 Fe $\mathrm{L}^{-1} \times 1000=\mathrm{mol} \mathrm{m}^{-3} \times 50 \mathrm{~m}=\mathrm{mol} \mathrm{m}^{-2} \times 0.13=\mathrm{mol} \mathrm{m}^{-2} \mathrm{~d}^{-1}$ ). This is considered to be a minimum

22 rate because it does not take into consideration potential losses of DFe due to coagulation, 
1 adsorption, precipitation, and sinking out of the upper mixed layer because quantifying these

2 processes would be overly speculative.

$4 \quad 4.2$ Potential DFe sources to surface waters of the RSP

$5 \quad$ Vertical DFe fluxes from sediments. Vertical exchange and reductive dissolution of sediment

6 are likely major DFe sources for the phytoplankton bloom in the RSP (Sedwick et al., 2011; De

7 Jong et al., 2013; Marsay et al., 2014). We measured the highest DFe concentrations of all

8 samples in the BNL, which was present in almost all stations we sampled during the cruise

9 (84\%). This suggests that kinetic energy from currents, tidal movements, or internal waves was

10 consistently high enough to resuspend sediments throughout the RSP (Dickson and McCave,

11 1986). Although, Marsay et al. (2014) observed a BNL at deeper stations in the RSP, during our

12 study, neither deep stations 43 and 44 in the Ross Trough nor shallow stations 60 and 61 on the

13 top of Pennell Bank had a BNL. Whether the absence of a BNL was a transient or a permanent

14 situation caused by low turbulence or a seafloor consisting of hard sediment or rock is not

15 known. Generally, the BNL has a high potential to scavenge dissolved trace metals and thus low

16 dissolved metal concentrations are expected (Bacon and Rutgers van der Loeff, 1989; Jeandel et

17 al., submitted). However, recently, the release of metals from suspended sediments as a source of

18 trace metals to the overlying waters has received more attention. Middag et al. (2011) and

19 Klunder et al. (2012) showed a release of dissolved Mn (DMn) and DFe near the Arctic

20 continental shelf from a nepheloid layer at intermediate depths. In addition, Hatta et al., (2013)

21 measured elevated concentrations of dissolved Fe, Mn, and Al in Southern Ocean waters where

22 resuspended sediments were detected near Drake Passage and concluded that resuspension plays 
1 an important role in enriching sea water with trace elements. Those findings are consistent with

2 our observations of elevated DFe in the BNL.

3 DFe was often higher in the upper BNL and decreased with depth within the BNL (see Fig

$4 \quad$ 7F). This pattern may be an indication of the release of DFe from the seafloor sediments. Two

5 potential processes releasing DFe from the sediment to the water include reductive dissolution

6 and sediment resuspension (a.o. Fitzwater et al., 2000; Sedwick et al, 2011; de Jong et al., 2013).

7 If reductive dissolution is the main process for DFe release, the released dissolved FeII will

8 oxidize in oxygenated waters to FeIII and will subsequently be precipitated and/or scavenged

9 and sink out. Thus, DFe concentrations will decrease further from the source, which was not

10 observed here. On the other hand, if the release is due to dissolution of DFe from resuspended

11 particles, scavenging by slowly sinking particles will decrease DFe concentrations close to the

12 seafloor, which was observed in the BNL. Dissolution of FeIII from resuspended sediment

13 particles is only possible if dissolved organic ligands are unsaturated and can bind FeIII, which is

14 the case here (unpublished results). In general, binding of FeIII by dissolved organic ligands

15 increases the residence time of DFe in the water column which makes it more available for

16 phytoplankton (Thuróczy et al., 2011; Gledhill and Buck, 2012).

17 To calculate the vertical diffusive DFe flux from the seafloor to the upper mixed layer where

18 phytoplankton uptake occurs, we estimated the vertical turbulent eddy diffusivity $\left(\mathrm{K}_{\mathrm{z}}\right)$ at every

19 station. We divided the water column into an upper mixed layer of $50 \mathrm{~m}$, a mid-depth layer with

20 gradually increasing DFe with depth and, if present, a BNL in which DFe concentration was

21 higher. At each station, we calculated the vertical gradients ( $\partial \mathrm{DFe} / \partial \mathrm{z})$ between BNL and the

22 water overlaying the BNL and between the water overlaying the BNL and the upper mixed layer.

23 Mean $\mathrm{K}_{\mathrm{z}}$ values were calculated for the layers in between (Fig. 8 and Supplementary Materials 
1 Table 2).At $84 \%$ of the stations, we obtained two DFe fluxes; one from the BNL (where present)

2 to just above the BNL where $\partial \mathrm{DFe} / \partial \mathrm{z}$ was strongest, and one from just above the BNL to the

3 upper mixed layer. In the RSP DFe fluxes varied between $1.3 \times 10^{-9}$ (st. 18) and $1.8 \times 10^{-6}$ (st. 49)

4 mol Fe m${ }^{-2}$ day $^{-1}$. Since $\mathrm{K}_{\mathrm{z}}$ was higher over the Ross and Pennell banks (Figs. 3-5,

5 Supplementary Materials Table 2), DFe fluxes were highest above slopes and tops of banks (Fig

6 8). The mean vertical DFe fluxes at stations on banks (st. 20, 30, 46, 47, 48, 49, 59, 60, 61, 113)

7 was $1.6 \times 10^{-7}$ mol DFe m${ }^{-2}$ day $^{-1}$ for both fluxes and $0.8 \times 10^{-7}$ mol DFe m$^{-2}$ day $^{-1}$ for the fluxes

8 from just above the BNL to the upper mixed layer. These fluxes to the upper mixed layer are 0.1

9 to 2.0 times the calculated DFe flux needed to sustain the phytoplankton bloom. The mean DFe

10 flux at stations in troughs is approximately a factor two lower $\left(3.3 \times 10^{-8} \mathrm{~mol} \mathrm{Fe} \mathrm{m}^{-2} \mathrm{day}^{-1}\right)$.

11 Moreover, the importance of a BNL for the DFe flux to the upper mixed layer is illustrated

12 comparing the DFe flux at bank station 60 without a BNL to the adjacent bank station 59 with a

13 BNL and approximately the same water depth, where the DFe flux was approximately ten times

14 higher. Marsay et al. (2014) used a regional circulation model of the Ross Sea to estimate $\mathrm{K}_{\mathrm{z}}$

15 values used for calculation of vertical DFe fluxes. Comparison of their model $\mathrm{K}_{\mathrm{z}}$ with our in situ

$16 \mathrm{~K}_{\mathrm{z}}$ estimates shows that our in situ median $\mathrm{K}_{\mathrm{z}}$ is approximately a factor 10 smaller than the

17 model $\mathrm{K}_{\mathrm{z}}$, which suggests a reasonably good agreement of the two methods considering that the

18 values range over four orders of magnitude. However, the spatial variation of our $\mathrm{K}_{\mathrm{z}}$ is a factor

$1910^{3}$ larger than the modeled $\mathrm{K}_{\mathrm{z}}$, suggesting greater natural variability in $\mathrm{K}_{\mathrm{z}}$ than what is produced

20 by a regional model. The mean $\mathrm{K}_{\mathrm{z}}$ values in the BNL were 3.2 times lower than those between

21 the BNL and upper mixed layer, showing that separating the water column below the upper

22 mixed layer into two layers based on the presence of a BNL is useful for calculations of both the

23 vertical $\mathrm{DFe}$ gradient $(\partial \mathrm{DFe} / \partial \mathrm{z})$ and $\mathrm{K}_{\mathrm{z}}$. The benthic DFe fluxes calculated by Marsay et al. 
1 (2014) from the sediment to $200 \mathrm{~m}$ depth, using their higher model $\mathrm{K}_{\mathrm{z}}$ values, are more than 10

2 times higher than our fluxes, ranging from $2.8 \times 10^{-8}-8.2 \times 10^{-6} \mathrm{~mol} \mathrm{DFe} \mathrm{m}^{-2} \mathrm{day}^{-1}$, with a

3 geometric mean of $3.7 \times 10^{-7} \mathrm{~mol} \mathrm{DFe} \mathrm{m}^{-2}$ day $^{-1}$. Our values range from $1.3 \times 10^{-9}$ to $1.8 \times 10^{-6} \mathrm{~mol}$

4 DFe m ${ }^{-2}$ day $^{-1}$ with a geometric mean from the BNL to the layer just above of $3.3 \times 10^{-8} \mathrm{~mol} \mathrm{DFe}$

$5 \mathrm{~m}^{-2}$ day $^{-1}$. These flux estimates are at the lower range of published vertical flux estimates

6 (Gerringa et al 2012, Marsay et al., 2014 and references therein).

$7 \quad$ Horizontal DFe fluxes from banks. Sediments from banks act as DFe sources to subsurface

8 waters via horizontal transport (Sedwick et al., 2011, De Jong et al., 2013). However, we

9 observed no subsurface DFe trends with distance from either the Ross Bank (Fig 3A) or the

10 Pennell Bank (Fig 4A). Thus, there were no indications that the banks were significant DFe

11 sources to deep waters in the Ross Sea via horizontal transport, despite the fact that the vertical

12 DFe fluxes over the banks were high (Figs. 7C and D).

13 Horizontal DFe fluxes from landmasses. Horizontal DFe transport from Franklin Island was

14 studied to understand the importance of landmasses as DFe source to the Ross Sea. Indeed, in the

15 Franklin Island transect, DFe concentration below $100 \mathrm{~m}$ depth decreased with distance from

16 Franklin Island (Fig. 7E). No decrease was detected in surface waters $(<100 \mathrm{~m})$, since DFe was

17 low at all stations (Fig. 9), presumably due to phytoplankton uptake, as suggested by the high

18 fluorescence in surface waters. Since there was no horizontal DFe gradient in surface waters,, we

19 cannot calculate a horizontal DFe flux. In addition, horizontal DFe trends could not be obtained

20 in deep waters below $400 \mathrm{~m}$ since at this depth the distance to the BNL determines the DFe

21 concentration. However, we observed a decrease in DFe with distance from Franklin Island at

22 depths of $200 \mathrm{~m}$ and $300 \mathrm{~m}$ that we fitted exponentially to obtain the scale length over which the

23 DFe concentration at the source $\left(\mathrm{C}_{0}\right)$ is reduced to $0.37 \mathrm{C}_{0}$. The calculated scale lengths are 125 
1 and $60 \mathrm{~km}$ for 200 and $300 \mathrm{~m}$ depth, respectively. These scale lengths are in agreement with

2 published scale lengths of $16 \mathrm{~km}$ for surface waters in Monterey Bay (Johnson et al, 1997), 25

$3 \mathrm{~km}$ for the surface waters near Crozet Island and near the Antarctic Peninsula (Planquette et al.,

4 2007, Ardelan et al., 2010), $59 \mathrm{~km}$ for waters at $100 \mathrm{~m}$ depth in the Pine Island Polynya

5 (Gerringa et al., 2012), and $131 \mathrm{~km}$ for water at $40 \mathrm{~m}$ depth near the Kerguelen Islands

6 (Bucciarelli et al., 2001).

$7 \quad$ The scale lengths obtained here near Franklin Island result in horizontal fluxes at $200 \mathrm{~m}$ of

85.5 and $2.6 \times 10^{-5} \mathrm{~mol}$ DFe m${ }^{-2} \mathrm{~d}^{-1}$ and at $300 \mathrm{~m}$ of 5.0 and $3.4 \times 10^{-5} \mathrm{~mol} \mathrm{DFe} \mathrm{m}^{-2} \mathrm{~d}^{-1}$ at a

9 distance of 50 and $100 \mathrm{~km}$ from Franklin Island, respectively. To compare the transport of DFe

10 via horizontal flux $\left(\mathrm{F}_{\mathrm{h}}\right)$ with the supply needed to sustain phytoplankton growth in the upper

11 mixed layer, and with the vertical transport, we converted the net $\mathrm{F}_{\mathrm{h}}$ fluxes into units of volume.

12 We calculated the horizontal fluxes at $200 \mathrm{~m}$ depth at distances of 50 and $100 \mathrm{~km}$ from Franklin

13 Island and assumed the first flux to be the influx and the second flux to represent the outflux

14 from a box over the $50 \mathrm{~km}$ distance difference. The difference between these fluxes divided by

15 the distance between in- and outflux is the net horizontal flux or transport of DFe $\left(\left(\mathrm{F}_{\mathrm{h}}(50 \mathrm{~km})\right.\right.$ -

$\left.\left.16 \mathrm{~F}_{\mathrm{h}}(100 \mathrm{~km})\right) / 50 \mathrm{~km}\right)$. This results in a net flux of 3.3 to $5.8 \times 10^{-10} \mathrm{~mol} \mathrm{DFe} \mathrm{m}^{-3} \mathrm{~d}^{-1}$. Since the

17 vertical DFe-transport is calculated to the upper $50 \mathrm{~m}$, the average MLD, we divided the vertical

18 transport by 50, to compare both fluxes in the same units. This resulted in vertical diffusive

19 fluxes of 6.7 to $4.3 \times 10^{-10} \mathrm{~mol} \mathrm{DFe} \mathrm{m}{ }^{-2} \mathrm{~d}^{-1}$ (using $3.3 \times 10^{-8} \mathrm{~mol} \mathrm{DFe} \mathrm{m}^{-2}$ day $^{-1}$, which is the mean

20 for all the fluxes from just above the BNL to the upper mixed layer, and $2.1 \times 10^{-8} \mathrm{~mol} \mathrm{DFe} \mathrm{m}^{-2}$

21 day, which is the mean of the fluxes for the stations 88-90 near Franklin Island from

22 Supplementary Materials Table 2). This calculation shows that at a horizontal distance between

2350 and $100 \mathrm{~km}$ from the source the horizontal transport at $200 \mathrm{~m}$ depth is approximately the 
1 same as the mean vertical transport, suggesting that the horizontal DFe flux from landmasses can

2 be important. However, vertical transport is needed to bring DFe up to the phytoplankton in the

3 upper mixed layer and this process likely becomes the determining factor for transport up to the

4 phytoplankton in the upper mixed layer.

$5 \quad$ Horizontal DFe fluxes from the Ross Ice Shelf. We did not discern horizontal trends in DFe

6 with distance from the RIS at any depth of the water column (Fig. 3A, 7B and C; Supplementary

7 Materials Table 1) and therefore, a horizontal DFe flux from the RIS to the RSP could not be

8 calculated. According to observations by Jacobs et al. (1970), Jacobs and Giulivi (1998), and

9 modeling by Holland et al. (2003), the main outflow of ISW from under the RIS is located just

10 west of $180^{\circ}$ where stations $43-45$ were located (Fig. 2B). The ISW distinguished at stations 44

11 and 45 contained slightly elevated DFe (Fig. 7B), indicating that the RIS may be a small DFe

12 source. However, our data suggest that the elevated DFe in ISW does not reach far into the

13 polynya. At greater distances from the RIS, the ISW forms SW, in which no elevated DFe was

14 detected. Therefore, we conclude that DFe in ISW is not a significant DFe source for the RSP, in

15 contrasts with the previous suggestions (Fitzwater et al., 2000; Sedwick et al. (2000). In contrast

16 to the RIS, the Pine Island Glacier was found to be the main source of DFe to the phytoplankton

17 bloom in the Pine Island Polynya (Gerringa et al 2012). An important difference between these

18 two glaciers is the size of the cavity below the floating glacier terminus and the direct access of

19 the relatively warm MCDW that drives basal melt in the Pine Island Glacier (Jacobs et al., 2011).

20 The cavity under the RIS is much larger than that under the Pine Island Glacier and during the

21 long time that the ice sheet is transported over this cavity, the bottom of the floating ice tongue is

22 slowly melting and, releasing its Fe into the water. Here, particles may sink and DFe may

23 aggregate and sink out of the water column. Moreover, the basal melt rate of the RIS is smaller 
1 than that of the Pine Island Glacier (Rignot et al., 2013). We did not observe any hints of particle

2 outflow from under the RIS as the transmission in waters below the euphotic zone close to the

3 RIS was near $100 \%$.

$4 \quad$ DFe fluxes from deep water masses. CDW has elevated DFe compared to AASW (Klunder et 5 al., 2011; Sedwick et al., 2011) and may thus be a DFe source to surface waters. CDW may be a 6 direct DFe source to the RSP (Sedwick et al., 2011) and/or MCDW may be enriched with DFe

7 from sediments as it flows over the shelf (Gerringa et al., 2012). MCDW was only observed as a

8 deep water mass in the northern Ross Sea, at stations 60 and 61. This MCDW had low DFe $(0.20$

9 and $0.23 \mathrm{nM}$ at st. 60 and 61, respectively), even though it had already traveled over the seafloor

10 from the shelf break. Thus, MCDW does not appear to be a DFe source to the RSP. In fact,

11 stations 60 and 61 have the lowest DFe in the deepest sample of all stations in the RSP.

12 Sea ice. DFe may accumulate in sea ice, either due to atmospheric dust deposition over time

13 (Sedwick et al., 2010; De Jong et al., 2013) or remineralization of particulate Fe from ice algae

14 by the heterotrophic activity of bacteria and protozoa within the ice (Sedwick and DiTullio,

15 1997; Lannuzel et al., 2010, 2014; van der Merwe et al., 2011). This DFe is released in surface

16 waters when the sea ice melts (Sedwick et al., 2010; De Jong et al., 2013). In general dust is not

17 considered to be an important source of DFe for the nearshore waters of Antarctica (Martin et al.,

18 1990). Atmospheric dust quantities in the Southern Ocean are among the lowest in the world

19 (Duce and Tindale, 1991). However, the Ross Sea may be an exception due to the proximity of

20 sources of windblown particles such as the McMurdo Ice Shelf, the Dry Valleys, Ross Island,

21 and Erebus volcanic emissions. Thus, atmospheric dust deposition may be an important DFe

22 source for sea ice in the Ross Sea (Sedwick et al., 2011; De Jong et al., 2013). 
We sampled only four stations with a considerable sea ice cover in the northern RSP and the

2 Franklin Island transect. Elevated DFe in surface waters was only observed at one of these

3 stations, in the northern RSP (st. 60; Fig 7D). We used the turbulent eddy diffusivity coefficient

$4 \quad K_{z}$ (see below) to calculate the downward transport of DFe released from sea ice in the upper 10

$5 \mathrm{~m}$ (at station 60) to waters into the upper mixed layer below. This DFe flux from $10 \mathrm{~m}$ depth into

6 the mixed layer (10-56 m) was $5.6 \times 10^{-7}$ mol DFe $\mathrm{m}^{-2}$ day $^{-1}$, which is $0.2-4$ times the DFe flux

7 necessary to sustain the phytoplankton bloom. The other three stations with sea ice coverage

$8>50 \%$ were near Franklin Island and did not show elevated DFe (within the SD of the mean DFe)

9 in surface waters, suggesting either that there was no DFe input from melting sea ice or that it

10 was immediately taken up by phytoplankton. Our data show that sea ice may be a considerable

11 DFe source locally, but this effect was spatially highly variable. Although DFe from sea ice may

12 play an important role during the opening of the polynya and at the edges of the polynya, once it

13 is open, the effect is negligible in the RSP.

14 Icebergs. Icebergs may be a DFe source to surface waters which on occasion may be important

15 to the RSP (De Baar et al. 1995; Sedwick et al., 2011). However, they can also be the cause of a

16 reduction in primary production in the RSP. In 2000 and in 2002, enormous icebergs (B-15 and

17 C-19, respectively) did calve off the front of the Ross Ice Shelf and prevented sea ice from

18 advecting out of the Ross Sea polynya. The polynya was much smaller than normal and primary

19 production was greatly reduced (Arrigo and Van Dijken, 2003b). Since we did not encounter any

20 icebergs in the RSP during the NBP 13-10 cruise, they cannot be considered here.

22 5. Conclusions 
DFe concentrations in surface waters ( $<100 \mathrm{~m}$ depth) of the RSP were low $(<0.1 \mathrm{nM})$ during

2 early summer, coinciding with the annual phytoplankton spring-summer bloom. DFe

3 concentrations increased with depth to 0.2-0.4 nM in deeper waters. The highest DFe

4 concentrations (up to $2.7 \mathrm{nM}$ ) were found within BNLs near the seafloor. At the few stations

5 where no BNL was present, DFe near the seafloor was lower.

6 Our investigation shows that during early summer the main DFe source to the phytoplankton

7 bloom was the vertical diffusive DFe transport from the seafloor sediments to the upper mixed

8 layer. The mean vertical DFe flux from waters above the BNL to the upper mixed layer was 3.3

$9 \times 10^{-8}$ mol DFe $\mathrm{m}^{-2} \mathrm{~d}^{-1}$. The greatest vertical DFe fluxes were observed above sediments with a

10 BNL In addition, vertical DFe fluxes were high above banks and slopes due to the smaller

11 distance to the source and to the larger $\mathrm{K}_{\mathrm{z}}$, reflecting greater turbulence. Stations near Franklin

12 Island showed that a horizontal flux from a landmass such as an island can be a substantial DFe

13 source to deep waters (<200 m depth). However, in early summer, when we sampled, no

14 transport from Franklin Island could be detected in the upper $100 \mathrm{~m}$. A horizontal gradient in

15 DFe from the island was observed only at 200 and $300 \mathrm{~m}$ depth and the net transport at a

16 distance between 50 and $100 \mathrm{~km}$ from the source was of the same magnitude as the vertical flux.

17 However, a mechanism for vertical transport is needed to bring this DFe to the upper mixed layer

18 where it may support primary productivity. We found no indication that the RIS is a significant

19 DFe source to the RSP, although we observed slightly elevated DFe in ISW (0.18 and 0.26 nM)

20 when compared to surrounding waters (0.12-0.15 nM). Sea ice was a minor DFe source near

21 Franklin Island. Only at one station in the marginal sea ice zone in the north of the polynya did

22 we find sea ice to be a sufficient DFe source to fuel the phytoplankton biomass levels that were

23 present. 
1 The finding that the vertical diffusive DFe flux was the main DFe source to the upper mixed

2 layer in the RSP suggests that the continental shelf width is an important feature supporting DFe

3 flux to the surface and supporting primary productivity (Arrigo et al, in prep). A wide shelf, such

4 as in the Ross Sea, provides a large area where exchange of DFe occurs, which can lead to a

5 substantial DFe flux to surface waters. However, our study shows that the vertical diffusive DFe

6 flux can vary by an order of magnitude between different stations, suggesting that local

7 conditions, such as the presence of a BNL and turbulence that enhances $K_{z}$, greatly affect $D F e$

8 fluxes to the upper mixed layer. Moreover, bathymetric features such as the Ross and Pennell

9 Banks greatly enhanced the vertical diffusive DFe flux, which is also expected to be high over

10 the Mawson Bank in the northwest RSP. Strikingly, satellite studies have revealed that the

11 phytoplankton biomass during the Austral summer (January and February) towards the end of

12 the growing season is higher over the Pennell and Mawson Banks (e.g. Reddy and Arrigo, 2006;

13 Smith et al. 2012). This suggests that the high vertical DFe fluxes over the banks are a permanent

14 feature in the RSP that supports phytoplankton productivity.

17 Acknowledgements

18 The authors are most grateful to Captain John Souza and crew of R.V.I.B. Nathaniel B.

19 Palmer, all Phantastic participants, as well as the excellent support by the Antarctic Support

20 Contract (ASC) technicians.

21 Nelleke Krijgsman (NIOZ) is acknowledged for improving the figures.

22 The US component of this research was sponsored by the National Science Foundation

23 Office of Polar Programs (Phantastic ANT-1063592 to KRA). 


\section{References}

Alderkamp, A.-C., Mills, M.M., van Dijken, G.L., Laan, P., Thuróczy, C-E., Gerringa, L.J.A., de Baar, H.J.W., Payne, C., Tortell, P., Visser, R.J.W., Buma, A.G.J., Arrigo, K.R., 2012. Iron from melting glaciers fuels phytoplankton blooms in Amundsen Sea (Southern Ocean); phytoplankton characteristics and productivity. Deep-Sea Res. II 71-76, 32-48.

Ainley, D.G., Ballard G., Dugger, K.M., 2006. Competition among penguins and cetaceans reveals trophic cascades in the western Ross Sea, Antarctica. Ecology 87, 2080-2093.

Arrigo, K.R., van Dijken, G.L., 2003a. Phytoplankton dynamics within 37 Antarctic coastal polynya systems. J. Geophys. Res., 108, NO. C8, 3271, doi:10.1029/2002JC001739.

Arrigo, KR, van Dijken, GL, 2003b.Impact of iceberg C-10 on Ross Sea primary production. Geophys. Res. Lett.,. 30, 1836, doi:10.1029/2003GL017721.

Arrigo, K.R., van Dijken, G.L., 2004. Annual changes in sea ice, chlorophyll $a$, and primary production in the Ross Sea, Antarctica. Deep-Sea Res. Part II. 51, 117-138.

Arrigo, K.R., Worthen, D.L., Robinson, D.H., 2003. A coupled ocean-ecosystem model of the Ross Sea. Iron regulation of phytoplankton taxonomic variability and primary production. J. Geophys.Res. 108, 3231, doi:10.1029/2001JC000856.

Arrigo, K.R., van Dijken, G.L., Bushinsky, S., 2008a. Primary Production in the Southern Ocean, 1997-2006. J. Geophys. Res. 113, C08004, doi:10.1029/2007JC004551.

Arrigo, K.R., van Dijken, G., Long, M., 2008b. Coastal Southern Ocean: A strong anthropogenic CO2 sink. Geophys. Res. Lett. 35, L21602, doi:10.1029/2008GL035624.

Aquilina, A., Homoky, W.B., Hawkes, J.A., Lyons, T.W., Mills, R.A., 2014. Hydrothermal sediments are a source of water column Fe and Mn in the Bransfield Strait, Antarctica. Geochim. Cosmochim. Acta 137, 64-80.

de Baar, H.J.W., Buma, A.G.J., Nolting, R.F., Cadée, G.C., Jacques, G., Tréguer, P.J., 1990. On iron limitation of the Southern Ocean: experimental observation in the Weddell and Scotia Seas. Mar. Ecol. Progr. Ser. 65, 105-122.

de Baar, H.J.W., de Jong, J.T.M., Bakker, D.C.E., Loscher, B.M., Veth, C., Bathmann, U., Smetacek, V., 1995. Importance of iron for plankton blooms and carbon-dioxide drawdown in the Southern Ocean. Nature 373, 412-415. 
1 Bacon, M.P., Rutgers van der Loeff, M.M., 1989. Removal of thorium-234 by scavenging in the 2 bottom nepheloid layer of the ocean. Earth Plan. Sci. Lett. 92, 157-164.

3 Blain, S., Quéguigiener, B., Armand, L., Belviso, S., Bombled, B., Bopp, L., Bowie, A., Brunet, 4 C., Brussaard, C., Carlotti, F., Christaki, U.,Corbière, A., Durand, I., Ebersbach, F., Fuda, J5 L., Garcia, N., Gerringa, L., Griffiths, B., Guigue, C., Guillerm, C., Jacquet, S., Jeandel, C., 6 Laan, P., Lefèvre, D., Lomonaco, C., Malits, A., Mosseri, J., Obernosterer, I., Park, Y-H., 7 Picheral, M., Pondaven, P., Remenyi, T., Sandroni, V., Sarthou, G., Savoye, N., Scouarnec, 8 L., Souhaut, M., Thuiller, D., Timmermans, K., Trull, T., Uitz, J., van-Beek, P., Veldhuis, $9 \quad$ M., Vincent, D., Viollier, E., Vong, L., Wagener, T., 2007. The effect of natural iron fertilization on carbon sequestration in the Southern Ocean. Nature 446, 1070-1075.

Blain, S., Sarthou, G., Laan, P., 2008. Distribution of dissolved iron during the natural iron fertilisation experiment KEOPS (Kerguelen Plateau, Southern Ocean). Deep-Sea Res. II 55, 594-605.

Boyd, P.W., Jickells, T., Law, C.S., Blain, S., Boyle, E.A., Buesseler, K.O., Coale, K.H., Cullen, J.J., De Baar, H.J.W., Follows, M., Harvey, M., Lancelot, C., Levasseur, M., Owens, N.P.J., Pollard, R., Rivkin, R.B., Sarmiento, J., Schoemann, V., Smetacek, V., Takeda, S., Tsuda, A., Turner, S., Watson, A.J., 2007. Mesoscale iron enrichment experiments 1993-2005: Synthesis and future directions. Science 315, 612-617.

Boyd, P.W., Arrigo, K.R., Strzepek, R., van Dijken, G.L., 2012. Mapping phytoplankton iron utilization: Insights into Southern Ocean supply mechanisms. J. Geophys. Res. 117, C06009, doi:10.1029/2011JC007726.

Bowie, A.R., van der Merwe, P., Quéroué, F., Trull, T., Fourquez, M., Planchon, F., Sarthou, G., Chever, F., Townsend, A., Obernosterer, I., Blain, S., 2014. Iron budgets for three distinct biogeochemical sites around the Kerguelen archipelago (Southern Ocean) during the natural fertilization experiment KEOPS-2. Biogeosci., submitted.

Boye, M., van den Berg, C.M.G., de Jong, J.T.M., Leach, H., Croot, P.L., de Baar, H.J.W., 2001. Organic complexation of iron in the Southern Ocean. Deep Sea Res. I 48, 1477-1497.

Buma, A.G.J., de Baar, H.J.W., Nolting, R.F., van Bennekom, A.J., 1991. Metal enrichment experiments in the Weddell-Scotia Seas: effects of Fe and Mn on various plankton communities, Limnol. Oceanogr. 36, 1865-1878. 
1 Bruland, K.W., Rue, E.L., Smith, G.J., 2001. Iron and macronutrients in California coastal

2 upwelling regimes: Implications for diatom blooms. Limnol. Oceanogr. 46, 1661-1674.

3 Coale, K.H., Johnson, K.S., Fitzwater, S.E., Gordon, R.M., Tanner, S., Chavez, F.P., Ferioli, L.,

4 Sakamoto, C., Rogers, P., Millero, F., Steinberg, P., Nightingale, P., Cooper, D., Cochlan,

$5 \quad$ W.P., Landry, M.R., Constantinou, J., Rollwagen, G., Trasvina, A., Kudela, R., 1996. A

6 massive phytoplankton bloom induced by an ecosystem-scale iron fertilisation experiment in

7 the equatorial Pacific Ocean. Nature 383, 495-501.

8 Coale, K.H., Gordon, R.M., Wang, X., 2005. The distribution and behavior of dissolved and

9 particulate iron and zinc in the Ross Sea and Antarctic Circumpolar Current along $170^{\circ} \mathrm{W}$.

10 Deep-Sea Res. I 52, 295-318.

11 Croot, P.L., Johanson M., 2000. Determination of iron speciation by cathodic stripping

12 voltammetry in seawater using the competing ligand 2-(2-Thiazolylazo)-p-cresol (TAC).

13 Electroanalysis 12, 565-576.

14 Croot, P.L., Andersson, K., Öztürk, M., Turner, D.R., 2004. The distribution and speciation of

15 iron along $6^{\circ} \mathrm{E}$ in the Southern Ocean. Deep Sea Res, II 51, 2857-2879.

16 Croot, P.L., Frew, R.D., Sander, S., Hunter, K.A., Ellwood, M.J. Pickmere, S.E., Abraham, E.R.,

17 Law, C.S., Smith, M.J., Boyd, P.W., 2007. Physical mixing effects on iron biogeochemical

18 cycling: FeCycle experiment. J. Geophys. Res. 112, C06015, doi:10.1029/2006JC003748.

De Baar, H.J.W., Buma, A.G.J., Nolting, R.F., Cadee, G.C., Jacques, G., Tréguer, P.J., 1990. On iron limitation of the Southern Ocean: experimental observations in the Weddell and Scotia Seas. Mar. Ecol. Progress Ser. 65, 105-122.

De Baar, H.J.W., Boyd, P.W., Coale, K.H., Landry, M.R., Tsuda, A., Assmy, P., Bakker, D.C.E.,

De Baar, H.J.W., de Jong, J.T.M., Bakker, D.C.E., Löscher, B.M., Veth, C., Bathmann, U., Smetacek, V., 1995. Importance of iron for phytoplankton spring blooms and CO2 drawdown in the Southern Ocean. Nature 373, 412-415.

Bozec, Y., Barber, R.T., Brzezinski, M.A., Buesseler, K.O., Boye, M., Croot, P.L., Gervais, F., Gorbunov, M.Y., Harrison, P.J., Hiscock, W.T., Laan, P., Lancelot, C., Law, C.S., Levasseur, M., Marchetti, A., Millero, F.J., Nishioka, J., Nojiri, Y., van Oijen, T., Riebesell, U., Rijkenberg, M.J.A., Saito, H., Takeda, S., Timmermans, K.R., Veldhuis, M.J.W., Waite, A.M., Wong, C.S., 2005. Synthesis of iron fertilization experiments: from the iron age in the age of enlightenment. J. Geophys. Res. 110, C09S16, doi: 10.1029/2004JC00260. 
1 de Jong, J., Schoemann, V., Lannuzel, D., Croot, P., De Baar, H., Tison, J.-L., 2012. Natural iron

2 fertilization of the Atlantic sector of the Southern Ocean by continental shelf sources of the

3 Antarctic Peninsula. J. Geophys. Res. 117, G01029, doi:10.1029/2011JG001679.

4 de Jong, J., Schoemann, V., Maricq, N., Mattielli, N., Langhorne, P.,Haskell, T., Tison, J-L.,

5 2013. Iron in land-fast sea ice of McMurdo Sound derived from sediment resuspension and

6 wind-blown dust attributes to primary productivity in the Ross Sea, Antarctica. Mar. Chem.

$7 \quad 157,24-40$.

8 Dickson, R.R., McCave, I.N., 1986. Nepheloid layers on the continental slope west of Porcupine $9 \quad$ Banks. Deep-Sea Res. 33, 791-818.

10 Dillon, T.M., 1982. Vertical overturns: a comparison of Thorpe and Ozmidov length scales. J.

11 Geophys. Res. 87, 9601-9613.

12 Duce, R.A., Tindale, N.W., 1991. Atmospheric transport of iron and its deposition in the ocean.

13 Limnol. Oceanogr. 36, 1715-1726.

14 Fitzwater, S.E., Johnson, K.S., Gordon, R.M., Coale, K.H., Smith, W.O. Jr., 2000. Trace metal

15 concentrations in the Ross Sea and their relationship with nutrients and phytoplankton

16 growth. Deep-Sea Res. II 47, 3159-3179.

17 Garcia, N. S., Sedwick, P. N., DiTullio, G. R., 2009. Influence of irradiance and iron on the

18 growth of colonial Phaeocystis antarctica: Implications for seasonal bloom dynamics in the Ross Sea, Antarctica, Aquat. Microb. Ecol., 57, 203-220, doi:10.3354/ame01334.

Gargett, A., Garner, T., 2008. Determining Thorpe scales from ship-lowered CTD density profiles. J. Atmos. Ocean. Tech. 25, 1657-1670.

Gerringa, L.J.A., Herman, P.M.J., Poortvliet, T.C.W., 1995. Comparison of the linear Van den Berg / Ruzic transformation and a non-linear fit of the Langmuir isotherm applied to $\mathrm{Cu}$ speciation data in the estuarine environment. Mar. Chem. 48, 131-142.

Gerringa, L.J.A., Blain, S., Laan, P., Sarthou, G., Veldhuis, M.J.W., Brussaard, C.P.D., Viollier, E., Timmermans, K.R., 2008. Fe-containing dissolved organic ligands near the Kerguelen Archipelago in the Southern Ocean (Indian sector). Deep Sea Res. II 55, 606-621.

Gerringa, L.J.A., Alderkamp, A.-C., Laan, P., Thuróczy, C.-E., De Baar, H.J.W., Mills, M.M., van Dijken, G.L., van Haren, H., Arrigo, K.R., 2012. Iron from melting glaciers fuels the phytoplankton blooms in Amundsen Sea (Southern Ocean); iron biogeochemistry. Deep-Sea Res. II 71-76, 16-31. 
1 Gerringa, L.J.A., Rijkenberg, M.J.A., Thuróczy, C.-E., Maas, L.R.M., 2014. A critical look at the 2 calculation of the binding characteristics and concentration of iron complexing ligands in 3 seawater with suggested improvements. Environ. Chem. 11, 114-136.

4 Gledhill, M., van den Berg, C.M.G., 1994. Determination of complexation of iron (III) with 5 natural organic complexing ligands in seawater using cathodic stripping voltammetry. Mar. 6 Chem. 47, 41-54.

7 Hatta, M., Measures, C.I., Selph, K.E., Zhou, M., Hisock, W.T., 2013. Iron fluxes from the shelf 8 regions near the South Shetland Islands in the Drake Passage during the austral-winter 2006. 9 Deep-Sea Res. II 90, 89-101.

10 Hawkes J.A., Connelly D.P., Gledhill, M., Achterberg, E.P., 2013. The stabilization and 11 transportation of dissolved iron from high temperature hydrothermal vent systems. Earth 12 Planet. Sci. Lett. 375, 280-290.

13 Hosegood, P., van Haren, H., Veth, C. 2005. Mixing within the interior of the Faeroe-Shetland 14 Channel. J. Mar. Res. 63, 529-561.

15 Holland, D.M., Jacobs, S.S., Jenkins, A., 2003. Modelling the ocean circulation beneath the Ross

Jacobs, S.S., Amos, A.F., Bruchhausen, P.M., 1970. Ross Sea oceanography and Antarctic Bottom Water formation. Deep-Sea Res. 17, 935-962.

Jacobs, S.S., Giulivi, C.F., Mele, P.A., 2002. Freshening of the Ross Sea during the late 20th century. Science 297, 386-389.

Jacobs, S.S., Jenkins, A., Giulivi, C.F., Dutrieux, P., 2011. Stronger ocean circulation and increase melting under Pine Island Glacier ice shelf. Nature Geoscience, 4, 519-523. doi:10.1038/ngeo1188 (2011)

Jacobs S.S., Giulivi, C., 1998. Interannual ocean and sea ice variability in the Ross Sea. Antarc. Res. Ser. 75, 135-150.

Johnson, K.S., Boyle, E., Bruland, K., Measures, C., Moffett, J., Aquilarislas, A., Barbeau, K., Cai, Y., Chase, Z., Cullen, J., Doi., T., Elrod, V., Fitzwater, S., Gordon, M., King, A., Laan, P., Laglera-Baquer, L., Landing, W., Lohan, M., Mendez, J., Milne, A., Obata, H., Ossiander, L., Plant, J., Sarthou, G., Sedwick, P., Smith G.J., Sohst, B., Tanner, S., Van Den Berg, S., Wu, J., 2007. Developing standards for dissolved iron in seawater. Eos Trans. 88, 131. 
Johnson, K.S., Gordon, R.M., Coale, K.H., 1997. What controls dissolved iron concentrations in 2 the world ocean? Mar. Chem. 57, 137-161.

Jones, E.M., Bakker, D.C.E., Venables, H.J., Hardman-Mountford, N., this issue. Seasonal cycle of $\mathrm{CO} 2$ from the sea ice edge to island blooms in the Scotia Sea, Southern Ocean. Mar.

5 Chem., this issue.

Klunder, M.B., Laan, P., Middag, R., De Baar, H.J.W., van Ooijen, J.C., 2011. Dissolved Fe in

$$
\text { the Southern Ocean (Atlantic sector). Deep-Sea Res. II 58, 2678-2694. }
$$

Klunder, M.B., Laan, P., Middag, R., De Baar, H.J.W., Bakker, K., 2012. Dissolved iron in the Arctic Ocean: Important role of hydrothermal sources, shelf input and scavenging removal. J. Geophys Res. 117, C04014, doi:10.1029/2011JC007135.

Lannuzel, D., Schoemann, V., de Jong, J., Pasquer, B., van der Merwe, P., Masson, F., Tison, J.L., Bowie, A., 2010. Distribution of dissolved iron in Antarctic sea ice: Spatial, seasonal, and inter-annual variability. J. Geophys. Res. 115, G03022, doi:10.1029/2009JG001031.

Lannuzel, D., Schoemann, van der Merwe, P., Townsend, A.T., Bowie, A., 2014. Size fractionation of iron, manganese and aluminium in Antarctic fast ice reveals a lithogenic origin and low iron solubility. Mar. Chem. 161: 47-56

Liu, X., Millero, F.J., 2002. The solubility of iron in seawater. Mar.Chem. 77, 43-54.

Löscher, B.M., De Baar, H.J.W., De Jong, J.T.M., Veth, C., Dehairs, F., 1997. The distribution of Fe in the Antarctic Circumpolar Current. Deep-Sea Res. II 44, 143-187.

Marsay, C.M., Sedwick, P.N., Dinniman, M.S., Barrett, P.M., Mack, S.L., McGillicuddy, D.J., 2014. Estimating the benthic efflux of dissolved iron on the Ross Sea continental shelf. Geophys Res. Lett., 41, 7576-7583, doi:10.1002/2014GL061684.

Martin, J.H., Fitzwater, S.E., Gordon, R.M., 1990. Iron deficiency limits phytoplankton growth in Antarctic waters. Glob. Biogeochem. Cyc. 4, 5-12.

Martin, J.H., Coale, K.H., Johnson, K.S., Fitzwater, S.E. Gordon, R.M., Tanner, S.J., Hunter, C.N., Elrod, V.A., Nowicki, J.L., Coley, T.L., Barber, R.T., Lindley, S., Watson, A.J., van Scoy, K., Law, C.S., Liddicoat, M.I., Ling, R., Station, T., Stockel, J., Collins, C., Anderson, A., Bidigare, R., Ondrusek, M., Latasa, M., Millero, F.J., Lee, K., Yao, W., Zhang, J.Z., Friederich, G., Sakamoto, C., Chavez, F., Buck, K., Kolber, Z., Green, R., Falkowski, P., Chisholm, S.W., Hoge, F., Swift, R., Yangel, J., Turner, S., Nightingale, P., Hatton, A., Liss, 
P., Tindale, N.W., 1994. Testing the iron hypothesis in ecosystems of the equatorial Pacific

2 Ocean. Nature 371, 123-129.

3 Middag, R., de Baar, H.J.W., Laan, P., Klunder, M.B., 2011. Fluvial and hydrothermal input of

4 manganese into the Arctic Ocean. Geochim. Cosmochim. Acta 75, 2393-2408.

5 Millero, F.J., 1998. Solubility of Fe(III) in seawater. Earth Planet. Sci. Lett. 154, 323-330.

6 Mitchell, B.G., Brody, E.A., Holm-Hansen, O., McClain, C., Bishop, J., 1991. Light limitation of

7 phytoplankton biomass and macronutrient utilization in the Southern Ocean. Limnol.

8 Oceanogr. 36, 1662-1677.

9 Nuester, J., Shema, S., Vermont, A., Fields, D.M., Twining, B.S., 2014. The regeneration of

10 highly bioavailable iron by meso- and microzooplankton. Limnol. Oceanogr. 59, 1399-1409.

11 Okubo, A., 1971. Oceanic diffusion diagrams. Deep-Sea Res. 18, 789-802.

12 Raiswell, R., Tranter, M., Benning, L.G., Siegert, M., Death, R., Huybrechts, P., Payne, T., 2006.

13 Contributions from glacially derived sediment to the global iron (oxyhydr)oxide cycle:

14 implications for iron delivery to the oceans. Geochim. Cosmochim. Acta 70, 2765-2780.

15 Raiswell, R., Benning, L.G., Tranter, M., Tulaczyk, S., 2008. Bioavailable iron in the Southern

16 Ocean: the significance of the iceberg conveyor belt. Geochem. Trans. 9, 7

17 doi:10.1186/1467-4866-9-7.

18 Reddy, T.E., Arrigo. K.R., 2006. Constraints on the extent of the Ross Sea phytoplankton bloom.

J. Geophys. Res., Vol. 111, No. C7, C07005, 10.1029/2005JC003339.

Rignot, E., Jacobs, S., Mouginot, J, Scheuchl, B., 2013, Ice-shelf melting around Antarctica. Science 341, 266-270.

22 Sarmiento, J.L., Slater, R., Barber, R., Bopp, L., Doney, S.C., Hirst, A.C., Kleypas, J., Matear, ocean ecosystems to climate warming. Glob. Biogeochem. Cyc. 18, GB3003, doi:10.1029/2003GB002134.

Sarthou, G., Vincent, D., Christaki, U., Obernosterer, I., Timmermans, K.R., Brussaard, C.P.D., 2008. The fate of biogenic iron during a phytoplankton bloom induced by natural fertilization: impact of copepod grazing. Deep-Sea Res. II 55, 734-751.

Sedwick, P.N., DiTullio, G.R., 1997. Regulation of algal blooms in Antarctic shelf waters by the release of iron from melting sea ice. Geophys. Res. Lett. 24, 2515-2518. 
1 Sedwick, P.N., DiTullio, G.R., Mackey, D.J., 2000. Iron and manganese in the Ross Sea,

2 Antarctica: Seasonal iron limitation in Antarctic shelf waters. J. Geophys. Res. 105, 11321-

311336.

4 Sedwick, P.N., Bowie, A.R., Trull, T.W., 2008. Dissolved iron in the Australian sector of the

5 Southern Ocean (CLIVAR SR3 section); meridional and seasonal trends. Deep-Sea Res. I 55, 6 911-925.

7 Sedwick, P.N., Marsay, C.M., Sohst, B.M., Aguilar-Islas, A.M., Lohan, M.C., Long, M.C.,

8 Arrigo, K.R., Dunbar, R.B., Saito, M.A., Smith, W.O., Di Tullio, G.R., 2011. Early season

9 depletion of dissolved iron in the Ross Sea polynya: Implications for iron dynamics on the

10 Antarctic continental shelf, J. Geophys. Res., 116, C12019.

11 Smith, W.O., Barber, D.G., eds., 2007. Polynyas: Windows to the World. Elsevier Oceanography

12 Series, vol. 74, Elsevier, Amsterdam.

13 Smith Jr., W.O., Dinniman, M.S., Klinck, J.M., Hoffman, E.,2003. Biogeochemical

14 climatologies in the Ross Sea, Antarctica: seasonal patterns of nutrients and biomass. Deep-

15 Sea Research II 50, 3083-3101.

16 Smith, W.O., Shields, A.R., Peloquin, J.A., Catalano, G., Tozzi, S., Dinniman, M.S., Asper,

17 V.A., 2006. Interannual variations in nutrients, net community production, and

18 biogeochemical cycles in the Ross Sea. Deep-Sea Res. II, 53, 815-833.

Stansfield, K., Garrett, C., Dewey, R., 2001. The probability distribution of the Thorpe displacement within overturns in Juan de Fuca Strait. J. Phys. Oceanogr. 31, 3421-3434.

Strzepek, R.F., Maldonado, M.T., Hunter, K.A., Frew, R.D., Boyd, P.W., 2011. Adaptive strategies by Southern Ocean phytoplankton to lessen iron limitation: Uptake of organically complexed iron and reduced cellular iron requirements Limnol. Oceanogr. 56, 1983-2002.

Sunda, W.G., Huntsman, S.A., 1997. Interrelated influence of iron, light and cell size on marine phytoplankton growth. Nature 390, 389-392.

Tagliabue, A., Bopp, L., Dutay, J.-C., Bowie, A.R., Chever, F., Jean-Baptiste,.P., Bucciarelli, E., Lannuzel, D., Remenyi, T., Sarthou, G., Aumont, O., Gehlen, M., Jeandel, C., 2010. Hydrothermal contribution to the oceanic dissolved iron inventory. Nature Geosci. 14, 1-5, doi:10.1038/NGEO818.

Timmermans, K. R., Gerringa, L. J. A., de Baar, H. J. W., van der Wagt, B., Veldhuis, M. J. W., de Jong, J.T.M., Croot, P. L., Boye, M., 2001. Growth rates of large and small Southern 
Ocean diatoms in relation to availability of iron in natural seawater, Limnol. Oceanogr., 46, 260-266, doi:10.4319/lo.2001.46.2.0260.

Timmermans, K. R., van der Wagt, B. de Baar, H. J. W., 2004. Growth rates, half-saturation constants, and silicate, nitrate, and phosphate depletion in relation to iron availability of four large, open-ocean diatoms from the Southern Ocean, Limnol. Oceanogr., 49, 2141-2151, doi:10.4319/lo.2004.49.6.2141.

Tomczak, M., Godfrey, J.S., 2001. Regional Oceanography: an Introduction. Elsevier, Oxford. Thompson, P.A, Guo, M., Harrison, P.J., 1992. Effects of variation in the temperature. I. On the biochemical composition of eight species of marine phytoplankton. J. Phycol, 28, 481-488.

Thorpe, S.A., 1977. Turbulence and mixing in a Scottish Loch. Philos. Trans. Roy. Soc. Lond. A 286, 125-181.

Thuróczy, C.-E., Gerringa, L., Klunder, M., Laan, P., De Baar, H., 2011. Observation of consistent trends in the organic complexation of dissolved iron in the Atlantic sector of the Southern Ocean. Deep-Sea Res. II 58, 2695-2706.

Thuróczy, C-E, Alderkamp, A.-C., Laan, P, Gerringa, L.J.A., De Baar H.J.W., Arrigo, K.R., 2012. Key role of organic complexation of iron in sustaining phytoplankton blooms in the Pine Island and Amundsen Polynyas (Southern Ocean). Deep-Sea Res. II 71-76, 49-60.

Twining, B.S., Baines, S.B., Fischer, N.S., 2004. Element stoichiometries of individual plankton cells collected during the Southern Ocean Iron Experiment (SOFeX). Limnol. Oceanogr. 49, 2115-212.

van der Merwe, P., Lannuzel, D., Bowie, A.R., Meiners, K.M., 2011. High temporal resolution observations of spring fast-ice melt and seawater iron enrichment in East Antarctica. J. Geophys. Res. 116, G03017, doi:10.1029/2010JG001628.

van Haren, H., Gostiaux, L., 2014. Characterizing turbulent overturns in CTD-data. Dyn. Atmos. Oceans, 66, 58-76.

Wadham, J.L., Death, R., Monteiro, F.M., Tranter, M., Ridgwell, A., Raiswell, R., Tulaczyk, S., 2013. The potential role of the Antarctic Ice Sheet in global biogeochemical cycles. Earth Environ. Sci. Trans. Roy. Soc. Edinburgh 104, 1-13. 
Figure Captions

3 Figure 1: Station map of the Ross Sea during the Phantastic cruise. Stations 16, 17, and 18

4 are east of the various transects. The circle transect consists of the Central RSP, the Pennell Bank

5 and the Western RSP transects. All station numbers are specified per transect in the method

6 section 2.1. Station 114 has the same position as station 31.

8 Figure 2: Potential temperature $(\Theta)$-salinity plots of all stations in the Ross Sea Polynya (RSP).

9 Water masses indicated are: AntArctic Surface Water (AASW), Ice Shelf Water (ISW), Low

10 Salinity Shelf Water (LSSW), High Salinity Shelf Water (HSSW), Modified Shelf Water

11 (MSW), Circumpolar Deep Water (CDW), Modified Circumpolar Deep Water (MCDW), Winter

12 Water (WW).

13 2A: Eastern RSP (st. 16, 17) central RSP (st. 18 just east of central RSP transect, See Figure 1)

14 and the southern stations of the central RSP transect between the Ross Ice Shelf (RIS) and the

15 Ross Bank (the legend of the stations is from south to north).

16 2B: Northern part of the central RSP transect, from the Ross Bank to Pennell Bank (station 20-60

17 from south to north).

18 2C: Pennell Bank section (st. 61 - 75 from east to west).

19 2D: Western RSP transect including station 114 (st. 85-144 from north to south) and Franklin

20 Island transect (st. 88 - 90 from east to west with st. 89 closest to Franklin Island).

22 Figure 3: Water properties along the south-north central Ross Sea Polynya transect from the Ross 23 Ice Shelf at $77.74^{\circ} \mathrm{S}, 177.5^{\circ} \mathrm{E}$ at the left hand side to the north at the right hand side, crossing the 24 Ross Trough to the Ross Bank, crossing a smaller through to the Pennell Bank at $74.5^{\circ} \mathrm{S}$, $25 \quad 177.5^{\circ} \mathrm{E}$.

26 Dots indicate the stations; station numbers are indicated. A: DFe in nM; B: CTD fluorescence in 27 arbitrary units (a.u.), C: CTD transmission in \% from 95 to 100; D: potential temperature $\Theta$ in $28{ }^{\circ} \mathrm{C}$; E: CTD salinity; F: logarithm of $\mathrm{K}_{\mathrm{z}}$ in $\mathrm{m}^{2} \mathrm{~s}^{-1}$. 
1 St 44 is north of the RIS, st 44 and 45 are at the Ross Trough, st 46 is at Ross Bank and st 60 is

2 at Pennell Bank.

4 Figure 4: Water properties of the east-west Pennell Bank transect from the Pennell Bank at $574.5^{\circ} \mathrm{S}, 177.5^{\circ} \mathrm{E}$ at the right hand side west to the Joides Trough at $74.5^{\circ} \mathrm{S}, 172.5^{\circ} \mathrm{E}$ at the left

6 hand side. Dots indicate the stations; station numbers are indicated. A: DFe in nM; B: CTD

7 fluorescence in arbitrary units (a.u.), C: CTD transmission in \% from 95 to 100; D: potential

8 temperature $\Theta$ in ${ }^{\circ} \mathrm{C}$; E: CTD salinity; F: logarithm of $\mathrm{K}_{\mathrm{z}}$ in $\mathrm{m}^{2} \mathrm{~s}^{-1}$.

10 Figure 5: Water properties of west-east Franklin Island transect from close to Franklin Island at $1176.1^{\circ} \mathrm{S}, 168.7^{\circ} \mathrm{E}$ at the left hand side to $76.1^{\circ} \mathrm{S}, 170.2^{\circ} \mathrm{E}$ at the right hand side. Dots indicate the

12 station samples; station numbers are indicated. A: DFe in nM; B: CTD fluorescence in arbitrary

13 units (a.u.), C: CTD transmission in \% from 95 to 100; D: potential temperature $\Theta$ in ${ }^{\circ} \mathrm{C}$; E: CTD 14 salinity; $\mathrm{F}$ : logarithm of $\mathrm{K}_{\mathrm{z}}$ in $\mathrm{m}^{2} \mathrm{~s}^{-1}$.

16 Figure 6 Water properties of western Ross Sea Polynya transect, the north-south transect from 17 station $75\left(74.5^{\circ} \mathrm{S}, 172.5^{\circ} \mathrm{E}\right)$ at the right hand side to the south-west to station $101\left(76.5^{\circ} \mathrm{S}\right.$,

$\left.18171^{\circ} \mathrm{E}\right)$ and from there to the south-east to station $113\left(77.33^{\circ} \mathrm{S}, 177.5^{\circ} \mathrm{E}\right)$ at the left hand side 19 which has the same position as station 31 of the Central Ross Sea transect. Dots indicate the 20 station samples; station numbers are indicated. A: DFe in nM; B: CTD fluorescence in arbitrary 21 units (a.u.), C: CTD transmission in \% from 95 to 100; D: potential temperature $\Theta$ in ${ }^{\circ} \mathrm{C}$; E: CTD 22 salinity; F: logarithm of $\mathrm{K}_{\mathrm{z}}$ in $\mathrm{m}^{2} \mathrm{~s}^{-1}$.

24 Figure 7: DFe (nM) depth profiles, highlighting specific features explained in the text (data is in 25 Supplementary Materials Table 1).

26 7A: stations 16, 17 from the eastern Ross Sea Polynya (RSP) and station 18 east of the central 27 transect (see Fig.1), these stations are not shown in the transects (Figs. 3-6). 
1 7B: stations 44, 45 and 43 at the southern end of the central RSP transect close to the Ross Ice

2 Shelf (RIS) (transect in Fig 3). Scale is cut off at $0.5 \mathrm{nM}$ to show the elevated DFe in

3 Intermediate Shelf Water (ISW). The deep samples of st 43 falls is outside the plotted range, see

$4 \quad$ 7C for the full profile.

5 7C: stations at the southern end of the central RSP transect from the RIS Through to the Ross

6 Bank (incl station cut-off in B)

7 7D: stations from Pennell Bank transect to the Joides Through

8 7E: stations at the Franklin Island transect

9 7F: stations from the western RSP transect showing that in stations where the Bottom Nepheloid

10 Layer (BNL) was sampled (e.g st 86, 113, 114) DFe decreased towards the seafloor and the

11 highest DFe was found at some distance from the seafloor.

13 Figure 8: The logarithm of the vertical diffusive fluxes of Fe $\left(\mathrm{mol} \mathrm{m}^{-2}\right.$ day $\left.^{-1}\right)$ to the upper mixed

14 layer (50 m) calculated for the circle transect. This transect is the connection of the Central RSP,

15 the Pennell Bank and the Western RSP transects (Figure 1). Arrows indicate the position where

16 transects (Figures 3, 4 and 6) connect and change direction. The Franklin Island transect is not

17 part of this figure.

18

19 Figure 9: DFe for different depth ranges as a function of the distance to Franklin Island at

20 stations $88(9.5 \mathrm{~km}), 89(12.7 \mathrm{~km}), 90(16.5 \mathrm{~km})$ and $87(51.4 \mathrm{~km})$. The exponential equations

21 fitted to the decrease with distance are $\mathrm{f}(\mathrm{x})=0.2083 \mathrm{e}^{-0.008}$, and $\mathrm{f}(\mathrm{x})=0.3457 \mathrm{e}^{-0.015}$, at $200 \mathrm{~m}$, and

$22300 \mathrm{~m}$, respectively. $\mathrm{R}^{2}$ being 0.3719 , and 0.6466 , respectively) 


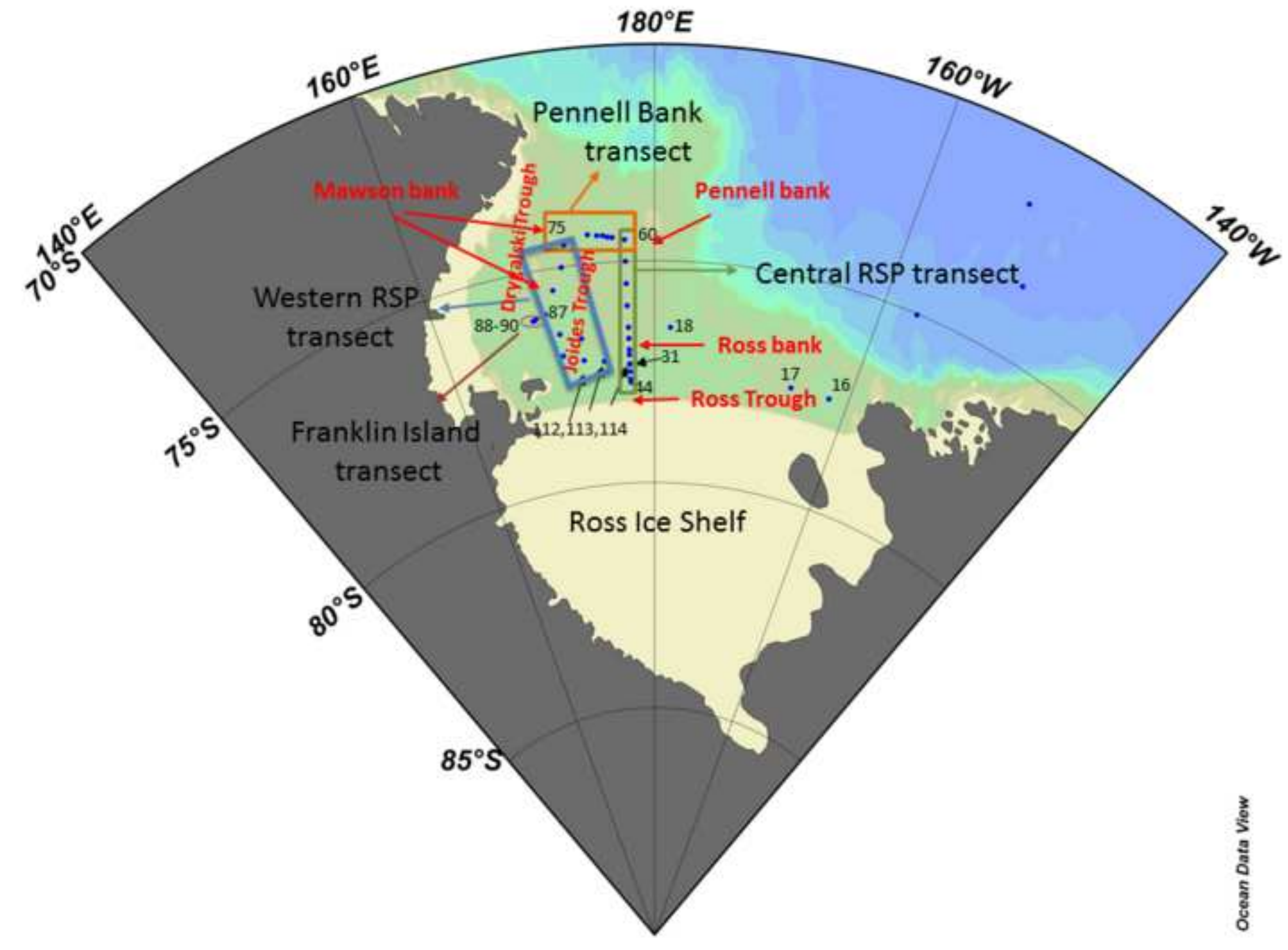



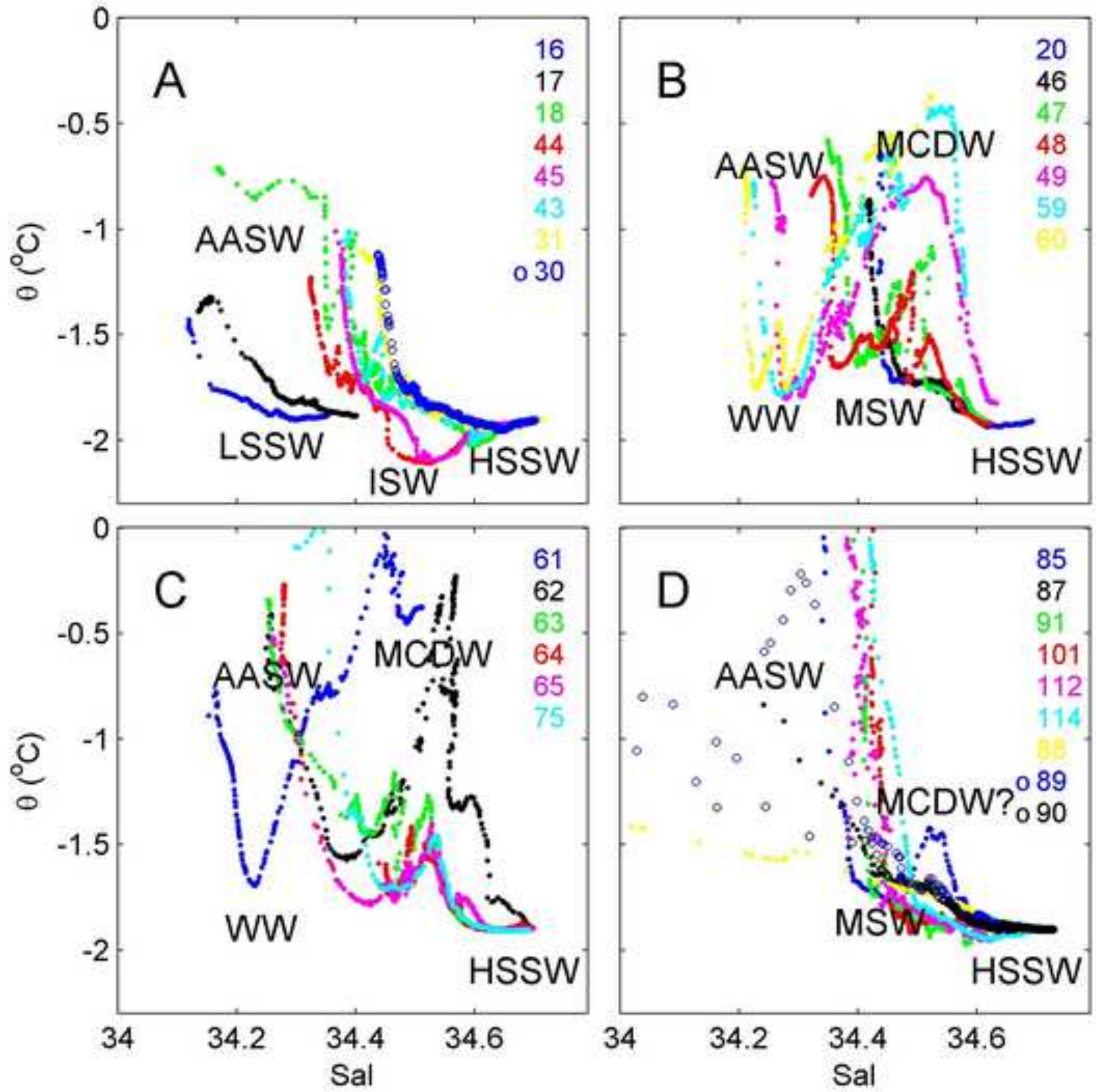

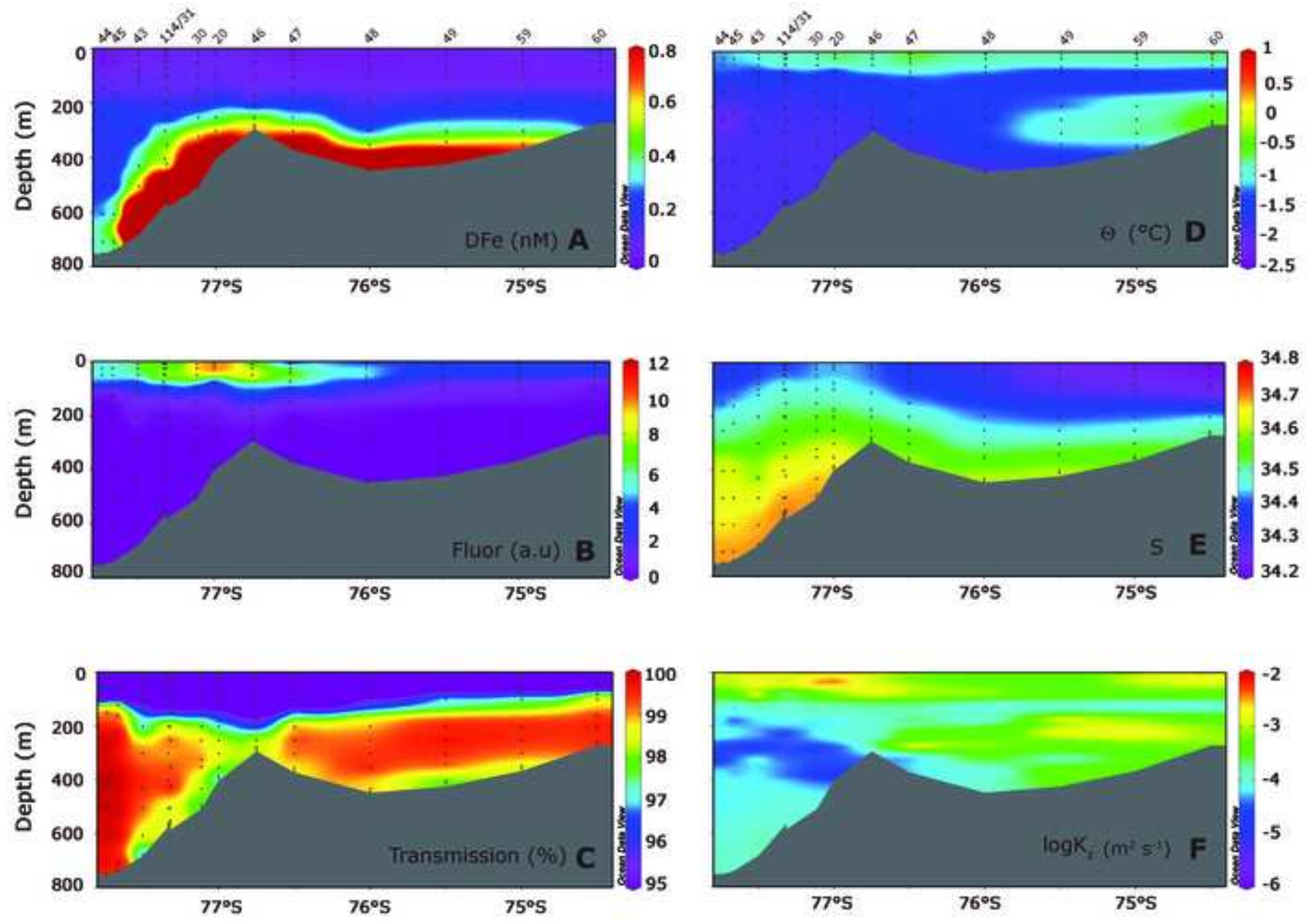

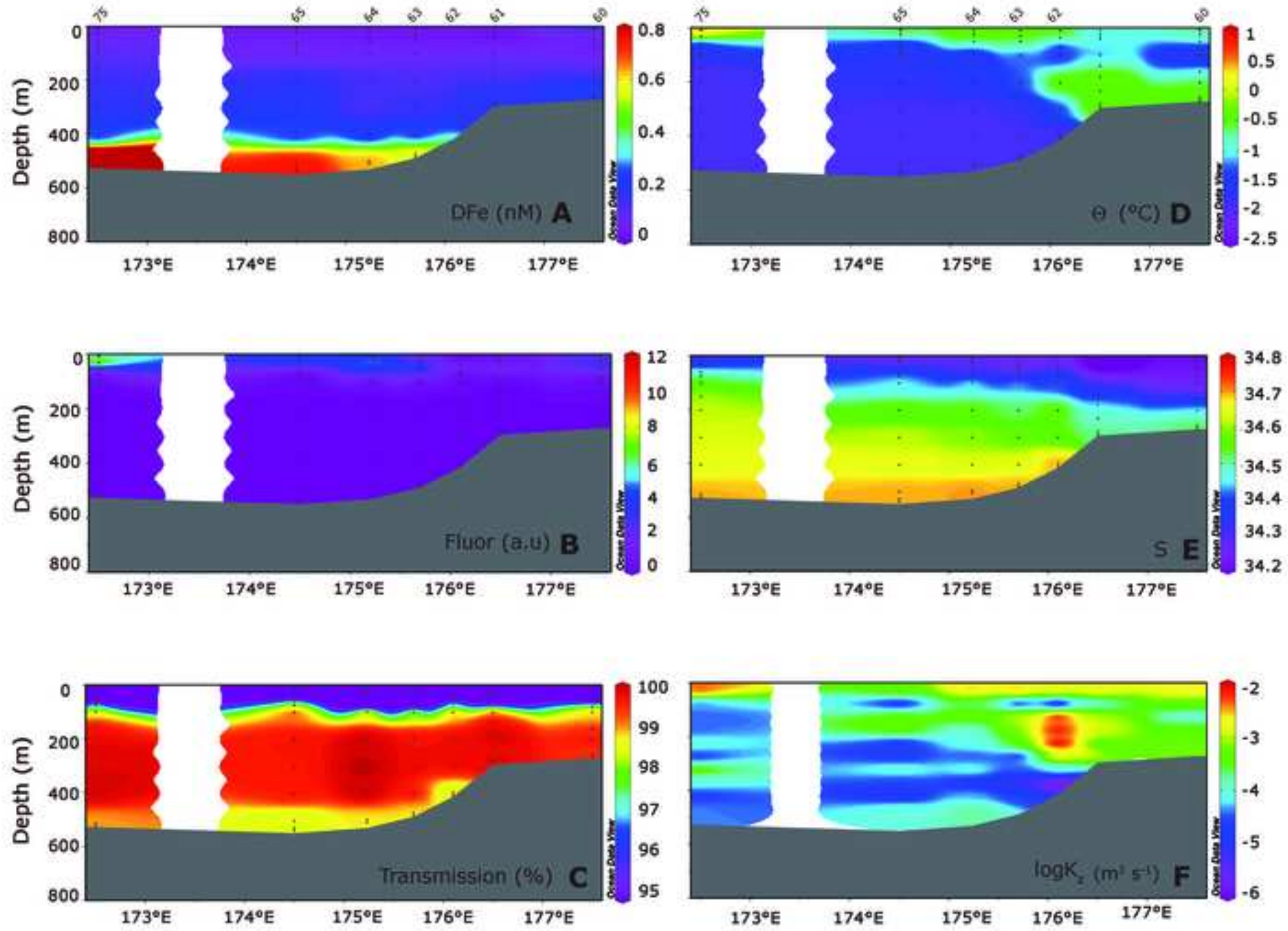

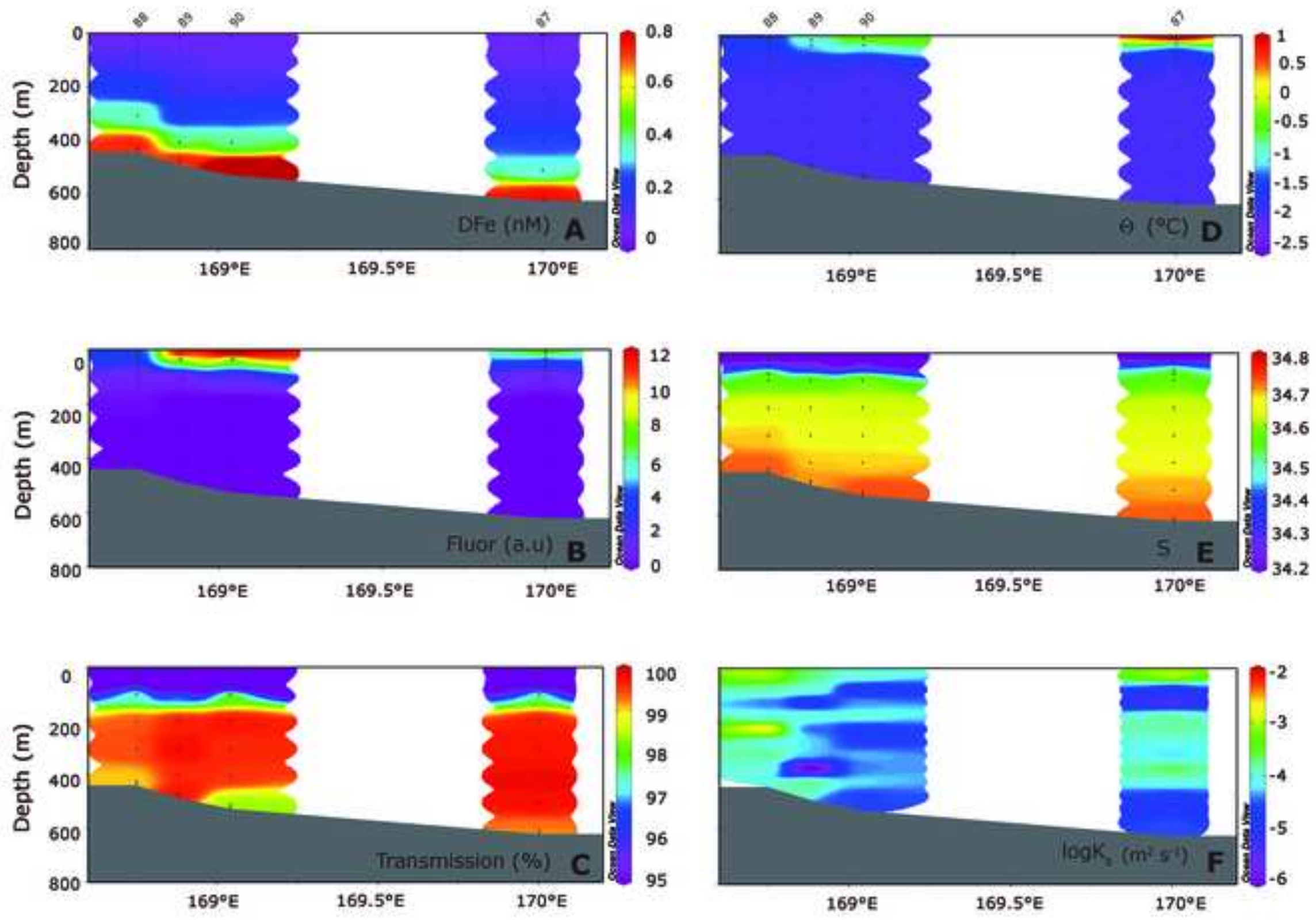

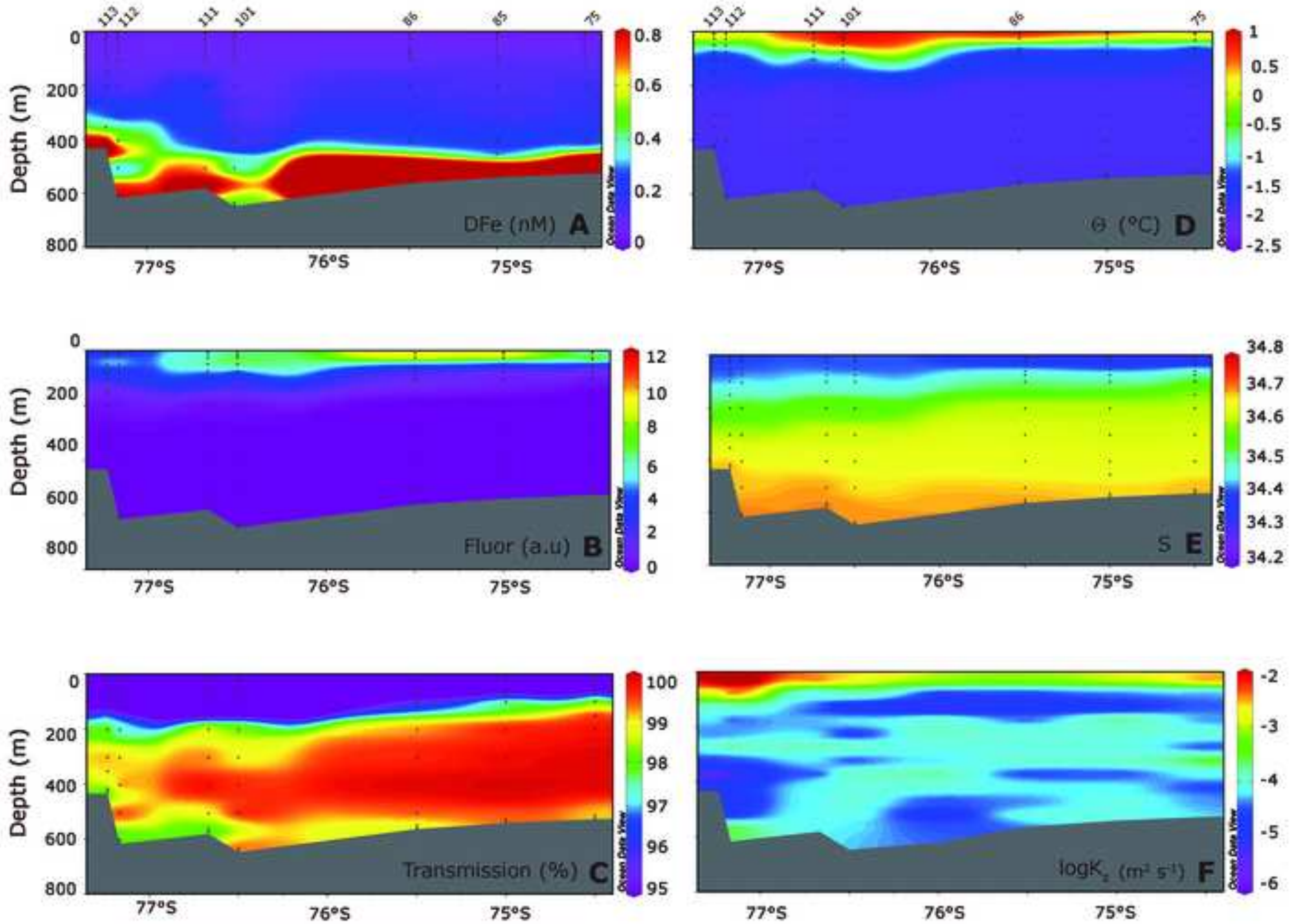

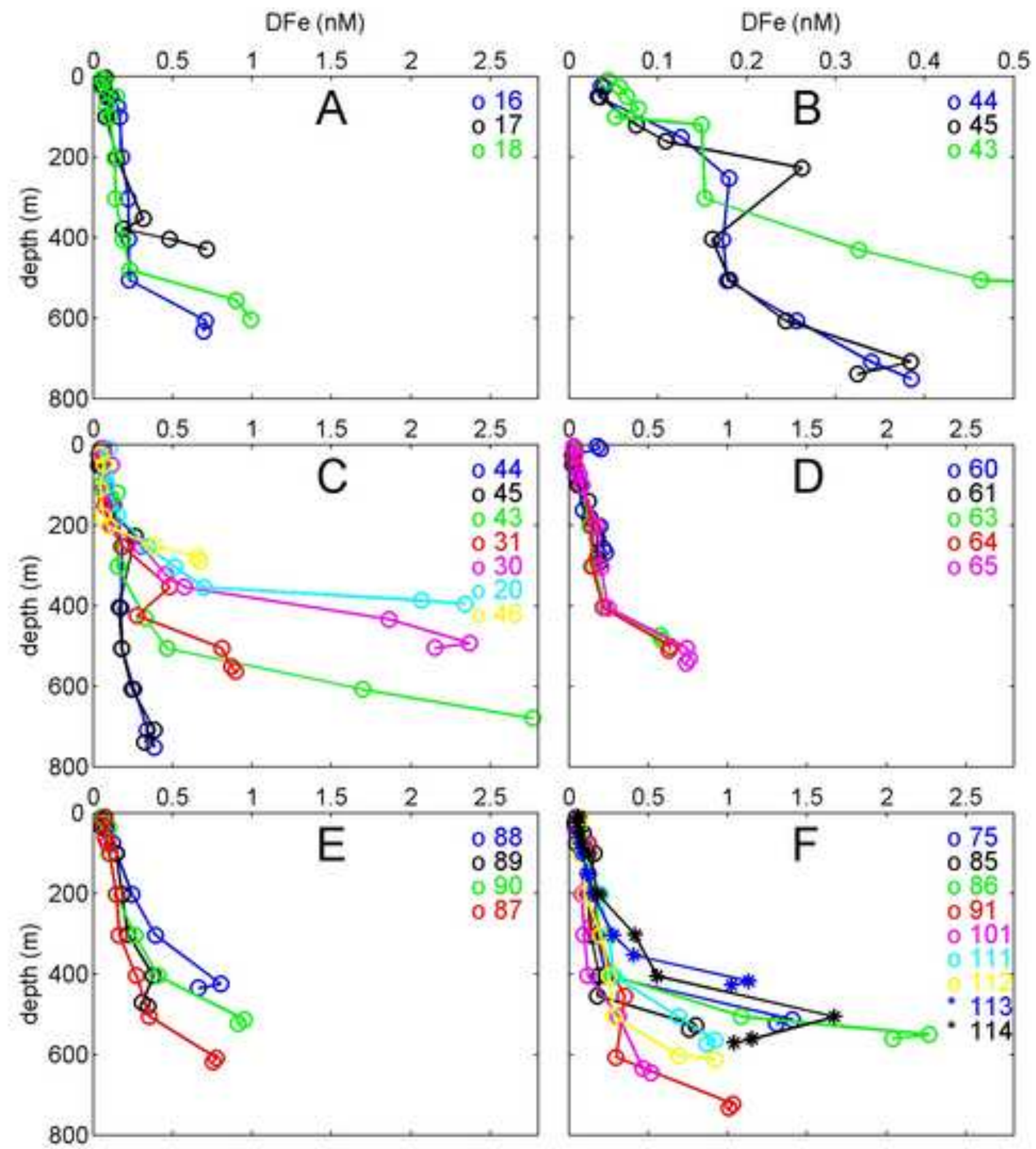


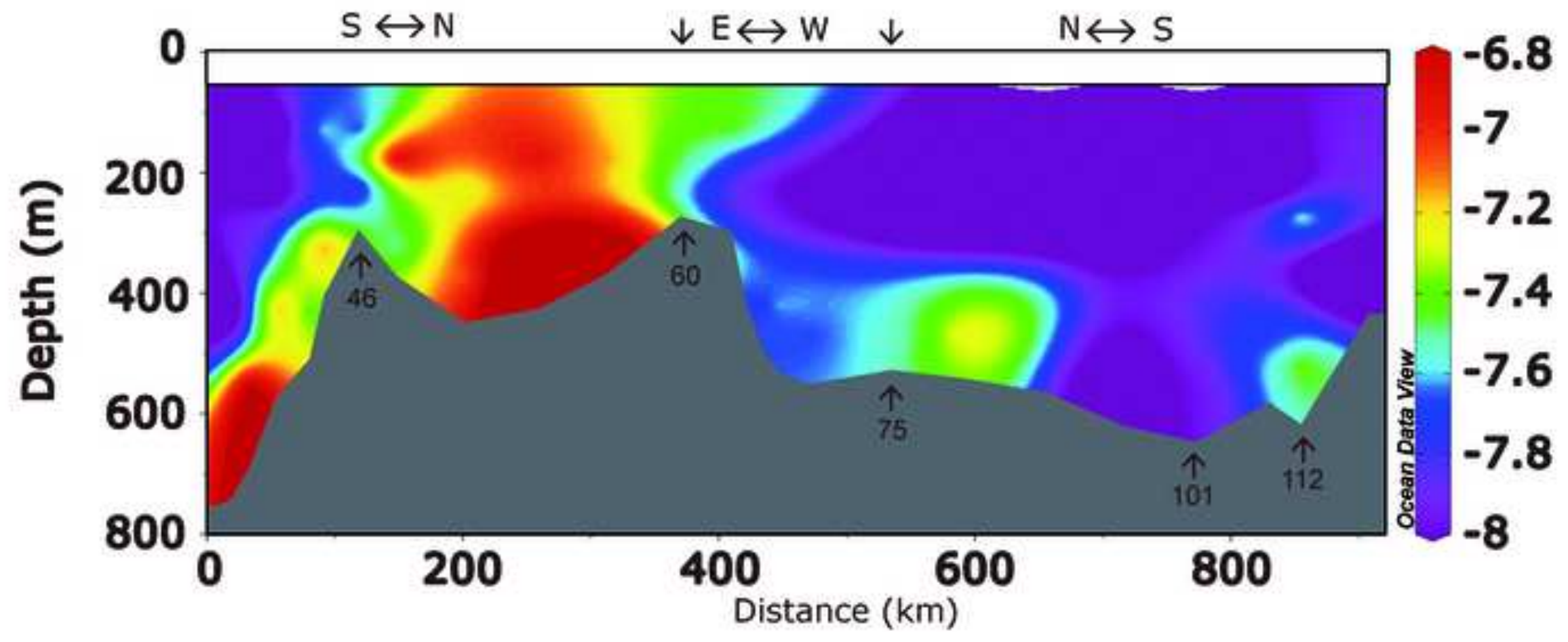




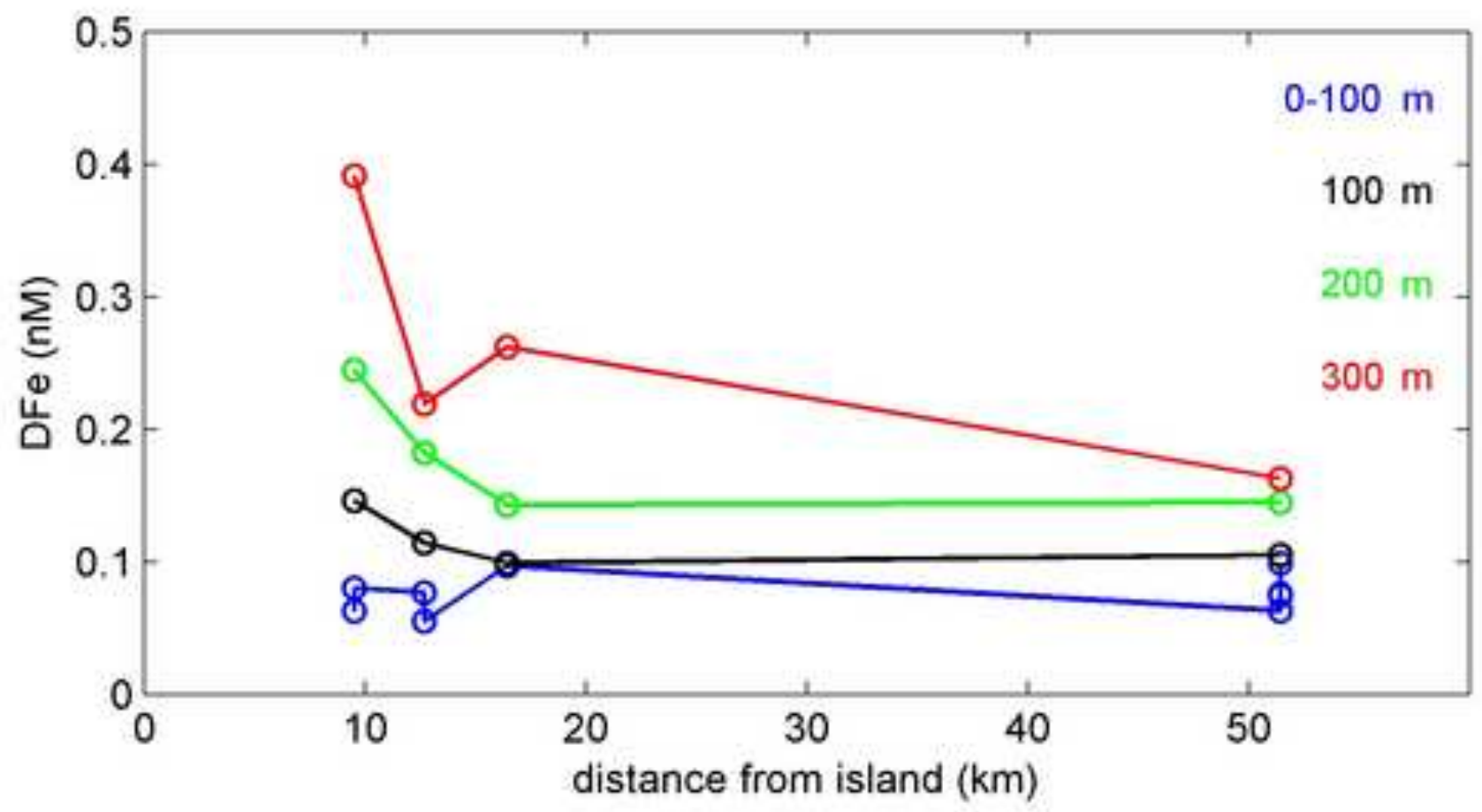

